\title{
PERSIAN POWDER FLASKS PRESERVED IN THE GAYER-ANDERSON MUSEUM IN CAIRO: AN ARCHAEOLOGICAL AND ARTISTIC STUDY
}

\author{
Hossam O. TANTAWY ${ }^{1}$ and Rehab I. ELSIEDY ${ }^{2}$ \\ ${ }^{1}$ Associate Professor, Faculty of Arts, Ain Shams University, Egypt \\ E-mail: hossam.awais@art.asu.edu.eg \\ ${ }^{2}$ Lecturer, Faculty of Archaeology, Cairo University, Egypt \\ E-mail: rehabelsiedy@,cu.edu.eg
}

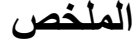

\begin{abstract}
Muslims had some contributions in using black powder in projectiles and firearms, as the pressure of military need has helped them develop all weapons which can catapult balls of fire. As a result of that, they make flasks to carry gunpowder. Nowadays, a lot of these powder flasks could be traced in museums and private collection all over the world. Gayer-Anderson Museum in Cairo has an important collection of Islamic powder flasks attributed to different regions made of different materials such as metal, wood, ivory, leather, etc. There are twelve of these powder flasks belonging to Iran as a type or place of manufacturing. These Persian powder flasks are distinguished by the variety of their shapes which could be divided into 4 main types. On the other hand, they reflect multiple methods in ornamenting this kind of object according to the type of the raw material it is made of. Despite the importance of this collection, there isn 't an individual study to explore them and reveal the different aspects which effect on such objects, so this research interests in studying this Persian collection of powder flasks descriptively and analytically.
\end{abstract}

\section{KEYWORDS} جاجاير أندرسون، بارود، حافظة، قرون، أسلحة، إيران،

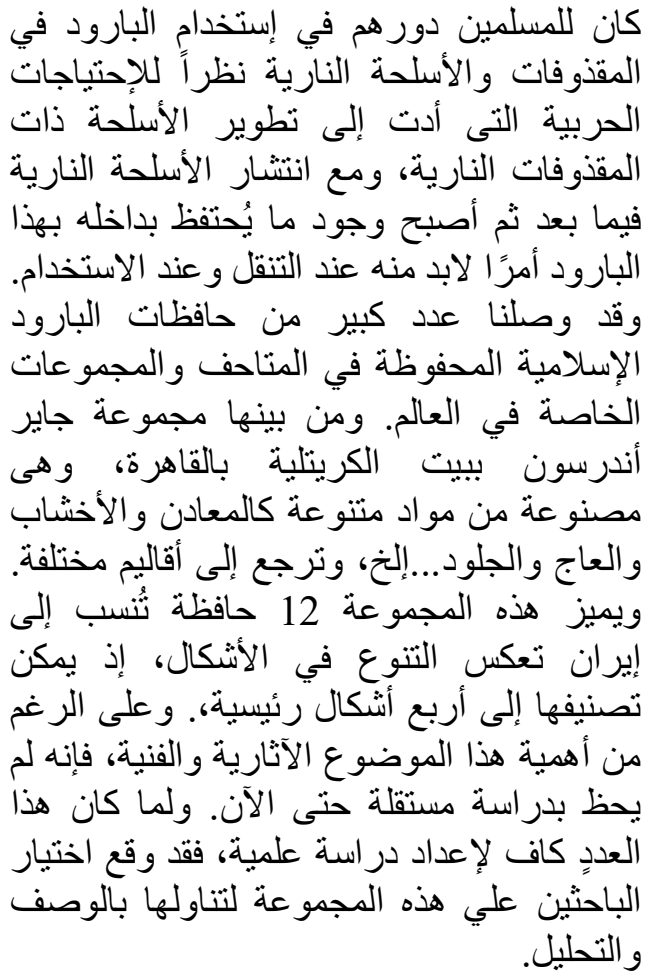

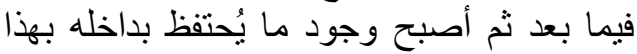
وقد وصلنا عدد كبير من حافظات البارود الإندات الإسلامية المحفوظة في المناحف و المجموعات الخاصة في العالم. ومن بينها مجموعة جاير

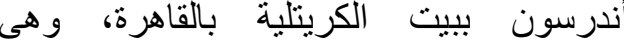
و العاج و الجلود....إلخ، وترجع دئ إلى أقاليم مختلفة.

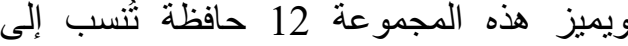
إيران تعكس التنوع في الأشكال، إذ بمكن الزئن

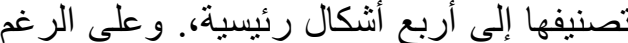

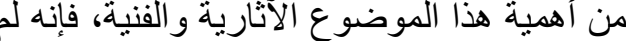
يحظ بدراسة مستقلة حتى الآن. ولما كان هذان الإنا العددٍ كاف لإعداد در اسة علمية، فقد وقع اختيار

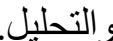
لبارود امرًا لابد منه عند التنقل و عند الاستخدام. مصنو عة من مو اد متنو عة كالمعادن والاختشاب

جاير أندرسون، بارود، حافظة، قرون، أسلحة، إيران، Iran, Qajar. 


\section{Introduction}

Black gunpowder ${ }^{1}$ is one of the most influential inventions in the world. It has not only radically changed ancient methods of war but has also extended to change the world ${ }^{2}$. This is due to be the invention which has accelerated the process of development of civilizations after it was used in many industrial and construction fields, the thing which puts black powder in category of the discoveries or inventions which have changed the course of humanity ${ }^{3}$.

Muslims had some contributions in using black powder in projectiles and firearms as the military need pushed them develop all weapons which can catapult balls of fire. They managed to create complex machines which look like canons or even surpass them ${ }^{4}$. Over time, the need for light weapons which can be carried paved the way to invent guns with shoulder support, which soldiers used in fighting. It was also used in hunting and shooting competition.

Rudimentary ${ }^{5}$ firearms ${ }^{6}$ first appeared in the $14^{\text {th }}$ century $\mathrm{AD} / 8^{\text {th }}$ century $\mathrm{AH}$. Europe

${ }^{1}$ Black powder is a mixture of Potassium nitrate, charcoal, and sulphur. However, there are black, yellow and white Islamic mixtures of powder. Ahmed, Al-Hadārah al-Islamiyh fĩ al-'Isūr al-Wustá, p.198; Hindī, "Al'Arab wa Ikhtra'a al-Barūd”, p.105; a group of scientists and researchers, Al-Mawsī'ah al-'Arabiyh al'Alamiyah, Vol (4), p.73; Al-Shakīl, Al-Qadhā'if wa-al-Aslihah al-Nariyah fì al-Hadāärah al-Islāmiyah, pp.119-120. In Persia, black powder is a loanword from Arabic language into Turkish. It is occasionally written as "bārut, باروط تفنى , باروط باروت “. For more details, see: Khorasani (Manouchehr Moshtagh), Lexicon of Arms and Armor from Iran, pp. 114- 115. The oldest usage of the Persian term "bārut" dates to the end of the $15^{\text {th }}$ century $\mathrm{AD} / 9^{\text {th }}$ century $\mathrm{AH}$. Some historical resources mention that preservation of powder and war requisites in 1503-1504 AD/ 908-909 AH occurred inside some fortifications of Persian cities such as Shūshtar. However, the word "barut" does not recur often in historical texts, while the same applies to firearms which demand the use of black powder. Large amounts of powder have been produced in dissimilar qualities in Persian cities, of which Isfahan comes on top of the list, where a number of powder makers- bārūtsāz- were employed in the arsenal. The powder produced in Lār- a city located in the southwest of Persia in Fars province- was of good quality. For more information, see: http://www.iranicaonline.org/articles/barut-alsobarut-and-barud-gunpowder-is-a-loanword-from-arabic-it-passed-from-turkish-into-persian-usage (accessed 24 July 2016).

${ }^{2}$ Al-Nahar, Al-Barū d al-Mutafajjir, http://www.albahethon.com/?page=show det\&id=1746 (accessed 18 July 2016).

${ }^{3}$ Hind̄̄ , Al-'Arab wa Ikhtra'a al-Barūd, p.94.

${ }^{4}$ For more information, see: Hindī, Al-'Arab wa Ikhtra'a al-Barūd, pp.101-107; Al-Shakīl, Al-Kimiya' fi alHad̄ārah al-Islamiyah, pp.138-141; Al-Shakīl, "Al-Qadhā'if wa-al-Asliḥah al-Nariyah fī al-Haḍārah alIslāmiyah", pp.112-121.; Ayalon, Gunpowder and Firearms in the Mamluk Kingdom, p.1-4.; Ágoston, Guns for the Sultan, p. 15.

${ }^{5}$ In Persia and East of the Islamic world, a rifle carries the name of 'tufang' or 'tufag' which linguistically indicates a single mobile firearm. Khorasani (Manouchehr Moshtagh), Lexicon of Arms and Armor from Iran, p.114.; Al-Kharrāt, Taṭawwur al-Aslihah al-Nariyah, p.170.

${ }^{6}$ Rifles have a long history of development stages starting as a model which carries the name of Arquebus which were used in Europe during the second half of the $14^{\text {th }}$ century $\mathrm{AD} / 8^{\text {th }}$ century $\mathrm{AH}$ and lasted until the $16 \mathrm{t}^{\mathrm{h}}$ century $\mathrm{AD} / 10^{\text {th }}$ century $\mathrm{AH}$, when muskets first appeared. They refer to the relatively heavy rudimentary rifles. The term "musket" was first used in Spain in the twenties of the 16th century, and it is believed that it relates to a Spanish infantry battalion. The name then moved to the rest of Western Europe and Russia. Musket may be derived from the Italian "moschetto" which stands for a small falcon, while some believe that Russia is the origin of the musket and that the name is derived from the old Russian name "Muscovy". Rifles of this type are 1.8 to 2 meters in length and 18 kilograms or more in weight. They shoot either a single cylindric bullet or a few lead bullets which are called projectiles that load from the muzzle and a trigger ignites the powder. The muskets are categorised into several classifications according to their firing mechanism and their future

- 139 - $\quad$ Persian Powder Flasks preserved in the Gayer- Anderson Museum in Cairo 
witnessed firearms development through inventing new systems with different ignition mechanisms between the beginning of the $15^{\text {th }}$ century $\mathrm{AD} / 9^{\text {th }}$ century $\mathrm{AH}$ and the middle of the $19^{\text {th }}$ century $\mathrm{AD} / 13^{\text {th }}$ century $\mathrm{AH}$. In each system, numerous ignition types appeared attributed either to the manufacturer or a development in its general appearance as in the double metal trigger, double barrel, or number of igniters in the same firearm. ${ }^{7}$ Black powder is the only ignition and firing element relied upon by all types of firearms throughout this historical period. Hence, the need of a container to hold the black powder becomes a necessity, taking into consideration the availability of a simple mechanism to store and carry during mobility and usage, and manufacturing the container from materials which match the nature of black powder as an inflammable substance.

Many Islamic powder flasks have reached us, made from different materials such as metal, wood, ivory, leather, etc. ${ }^{8}$ Multiple methods are used in shaping and ornamenting the flasks according to the type of the raw material it is made of. Some museums keep samples of those flasks ${ }^{9}$ while some other are kept in private collections. ${ }^{10}$ Moreover, there is a considerable number of flasks for sale in some international auction houses. ${ }^{11}$

Despite the importance of this monumental and artistic subject, it has not had an independent study until now. ${ }^{12}$ As the Gayer-Anderson ${ }^{13}$ collection of flasks in Bayt al-Kiritliya in

developments. For more information, see: Al-Mawsū'ah al-'Arabiyh al-'Alamiyah, vol. 5, pp. 145-149 and vol. 23, p. 262; Al-Kharrāt, Tațawwur al-Aslihah al-Nariyah, pp.171-178, 189-202.

${ }^{7}$ Al-Kharrāt, Tatawwur al-Aslihah al-Nariyah, p.202.

${ }^{8}$ Stone, A Glossary of the Construction, Decoration and Use of Arms and Armor, pp.515 - 516, fig.660.

${ }^{9}$ The Metropolitan Museum in New York has a big collection of Islamic and non-Islamic powder cases. The Islamic collection is distinguished by its geographic, temporal and artistic variety. http://www.metmuseum.org/search-results\#!/search?q=powder\%20flask\&page=1 (accessed 4 Aug. 2016). Ferenc Hopp Museum of Eastern Asiatic Arts in Budapest, Hungary, is another example which preserves one of the powder cases that attributes to India. Moreover, the Ethnographic Museum in Tehran preserves some other samples, two of which attribute to Persia in the $19^{\text {th }} \mathrm{AD} / 13^{\text {th }} \mathrm{AH}$ century. For more information, see: Kelényi and Szántó, Artisans at the Crossroads, pl. c.3.2.55.- c.3.2.58. The Louvre of Paris preserves two ivory powder cases inlaid with jade, gold, ruby, and turquoise. Their preservation numbers are "R. 436" and "R. 437" and they attribute to India during the $17^{\text {th }}$ century $\mathrm{AD} / 11^{\text {th }}$ century $\mathrm{AH}$. http://mini-site.louvre.fr/troisempires/fr/sculptures-incrustations-5-z2.php (accessed 21 July 2016). The Walters Art Museum of Baltimore preserves two ivory powder cases under preservation numbers 71.418 and 71.419 which attribute to India during the $18^{\text {th }}$ century $\mathrm{AD} / 12^{\text {th }}$ century $\mathrm{AH}$, or the first half of the $19^{\text {th }}$ century $\mathrm{AD} / 13^{\text {th }}$ century $\mathrm{AH}$. http://art.thewalters.org/detail/2698/primer/ and http://art.thewalters.org/detail/40388/powder-flask/ (accessed 21 July 2016). The Museum of Islamic Art in Cairo preserves an ivory powder case $13 \mathrm{~cm}$ in length under preservation number 4051. Although the Museum's records attribute it to Egypt during the Mamluk reign, this is incorrect and needs verification. Aḥmed, 'A 'mal al- 'ajj wa-al- 'zom fí Miṣr , p.234, Plate 70.

${ }^{10}$ An example of these private collections is Parviz Tanavoli's which keeps a number of them under no.51, no.219, no.220, no.220, no.223. They are made of different materials such as steels and wood and are all ascribed to the $18^{\text {th }}$ or $19^{\text {th }}$ century AD/ $12^{\text {th }}$ or $13^{\text {th }}$ century AH Persia. Allan and Gilmour, Persian Steel, pp.176-182.

http://www.christies.com/lotfinder/arms-armor/a-large-steel-and-brass-powder-horn-5422471-details.aspx; http://www.thirtyonehouse.com/\#!product/prd1/1991993765/18th-c.-persian-safavid-flask;

http://armsandantiques.com/product/search?search=persian+powder+flask

and http://www.ebay.co.uk/sch/i.html? from=R40\& trksid=p2047675.m570.11313.TR0.TRC0.H1.Xpersian + powd er+flask.TRS0\& nkw=persian+powder+flask\& sacat $=0$ (accessed 30 July 2016).

${ }^{12}$ Born's study of a group of powder flasks made of ivory that ascribe to Moghul India reign should be excluded. Born, Ivory Powder Flasks from the Mughal Period, pp.93-111.

${ }^{13}$ Gayer-Anderson Museum located in the two houses to the east of Ahmed ibn Tulun Mosque. One of the two houses dates back to $1540 \mathrm{AD} / 947 \mathrm{AH}$. It was established by Abdel-Qader Al-Haddad and is known by the name Amna bnt Salem. The other house was built by Mohamed ibn Salem Al-Gazzar in 1631 AD/ 1041 AH and is known by the name of Bayt al-Kiritliya as a reference to its last owner, a woman from Crete. The two 
Cairo ${ }^{14}$ includes a sufficient number to conduct a scientific study, the researchers choose this collection to describe and to analyze as follows:

\section{Descriptive Study ${ }^{15}$}

\subsection{Plate (1)}

Type: Priming flask.

Material: crucible (watered) steel (johar).

Dimensions $^{16}$ : Length: $17.5 \mathrm{~cm}$.

Registration number: 1663

Production place: Persia.

Technique: Casting, Soldering, Rivet

Weight: $264 \mathrm{~g}$.

Date: $19^{\text {th }}$ century $\mathrm{AD} / 13^{\text {th }}$ century $\mathrm{AH}$

Publication: First time.

Description: This priming flask is made of steel in the form of a curved cylinder horn with a tapering head. In the middle of the body of the flask, a valve fastened with rivets closes the narrow nozzle of the head. It works via a spring setup underneath the valve so that the opening of the nozzle can appear when the thumb presses the spring, the moving piece, under the valve. The valve is connected to two hollow circles via soldering. The other wide end of the bottom of the priming flask ends with an opening closed by a moving lid that is fixed in place spirally and connected to a small circular protrusion from the top. The whole body and attached parts of the horn shaped flask is completely plain.

\subsection{Plate (2)}

Type: Priming flask.

Material: crucible (watered) steel (johar). Technique: Casting, Soldering, Rivet

Dimensions: Length: $12 \mathrm{~cm}$.

Weight: $95 \mathrm{~g}$.

Registration number: 1664

Date: $19^{\text {th }}$ century $\mathrm{AD} / 13^{\text {th }}$ century $\mathrm{AH}$

Production place: Persia.

Publication: First time.

houses are together called al-Kiritliya House Museum. Robert Gayer-Anderson (1881 - 1945 AD) is the person behind the artistic collections compiled in the house. Anderson has been fond of collecting Oriental monuments. He asks the Arab Monuments Preservers Committee to hand the Kiritliya House over to him so that he may exhibit his Islamic collection. The committee agrees on the condition that the collection will be owned by Egypt after he leaves. Indeed, the House has been transformed into a museum at Anderson's behest, and he dedicates the House to the Egyptian Government when he leaves Egypt. Anderson is one of the most important orientalists and a collector of acquisitions and valuable masterpieces of his time simultaneously with his main job as a physician and an army officer, with his twin brother as his partner. Some international museums and private groups keep many acquisitions which belonged to Gayer-Anderson's collection. Among which the most important is Fitzwilliam Museum, which is located in Trumpington Street, Cambridge, United Kingdom. Anderson has presented over 7500 of the Egyptian masterpieces, which belong to different periods of time, but they richly belong to el-Amarinah period, to the museum to commemorate him and his twin brother. He has also requested that his collection be kept and shared in Egyptian monuments exhibitions under numbers starting with letters "E.GA".For more details, see: Brunner-Traut( Emma), Egyptian artists' sketches: figured ostraka from the Gayer-Anderson Collection in the Fitzwilliam Museum, 19.; Al-Bahnasy(Salah Ahmad), AlMatahif 'Ilm wa-Fann, 126.; Foxcroft (Louise), Gayer-Anderson The life and Afterlife of the Irish Pasha, 15.; http://www.fitzmuseum.cam.ac.uk/collections/egypt/collectionhistory/gayeranderson (accessed 19 Sep. 2016).

${ }^{14}$ Persian powder and priming flasks comprise the main core and the largest number among the GayerAnderson collection. Hence, the two researchers chose to restrict this study to only the said collection as there are only four other cases: one ascribes to Morocco, the second to India, the third to Europe and the fourth is Arab which makes them not eligible to be included in the study.

${ }^{15}$ The descriptive study does not include plates 13 to 20, as they have been mentioned only for clarification. 16 It is most unfortunate that there is lack of some data of the examined collection regarding length, width, thickness, diameter, and weight of each piece due to security procedures in the Gayer-Anderson Museum and some conditions related to the days assigned for photography.

- 141 - Persian Powder Flasks preserved in the Gayer- Anderson Museum in Cairo 
Description: This priming flask is made of steel in a form close to the shape of a tapered head arched horn. It is heavily rusted, but a professional restoration will surely reveal a Persian pattern welded steel. The difference lies in the fact that this horn is characterized with an angle larger than the simple inclination known of most of the natural horns of animals. While one of its sides is straight, the other three are cylindrical. A valve similar to the previously described is fixed in the middle of the straight side of the body, while the last part of the narrow nozzle closing valve is missing. The other wide side of the bottom of the horn-shaped flask ends in an opening which closes with a moving lid that is cylindrically fixed in place and connected to a small hollow circle from above. The whole body of the horn flask and its attached parts are completely plain.

\subsection{Plate (3)}

Type: Priming flask.

Material: crucible (watered) steel (johar). Technique: Casting, Soldering, Rivet

Dimensions: Length: $14 \mathrm{~cm}$.

Weight: $164 \mathrm{~g}$.

Registration number: 1666

Date: $19^{\text {th }}$ century $\mathrm{AD} / 13^{\text {th }}$ century AH

Production place: Persia

Publication: First time.

Description: The priming flask is made of steel and is similar in the overall design and the attached parts to the previously described one with Registration number 1664 (Pl. 2). It differs from the former in the presence of an ornamenting line circling around the wide top side of the horn base. This line consists of two thin protruding frames of contiguous granules which engulf three rows of incised pentagrams.

\subsection{Plate (4)}

Type: Priming flask.

Material: crucible (watered) steel (johar). Technique: Casting, Soldering, Rivet

Dimensions: Length: $15 \mathrm{~cm}$. Width: $5.5 \mathrm{~cm}$., Diameter: $2.2 \mathrm{~cm}$., Thickness: $0.1 \mathrm{~cm}$. Weight: $197 \mathrm{~g}$.

Registration number: 1667

Production place: Persia.
Date: $19^{\text {th }}$ century $\mathrm{AD} / 13^{\text {th }}$ century $\mathrm{AH}$

Publication: First time.

Description: This priming flask is similar to the two previously described ones carrying registration numbers 1664 and 1666 (Pls. 2/3), with the exception of the valve which differs from the previously described flasks - despite having similar functionality - regarding the composing parts. It consists of three metal pieces: two side pieces fixed at the end of the body of the flask from the wide side of the bottom of the horn. Their purpose is to fix the valve between them via a rivet. They are both hollow, which recurs in the tapering part at the end of the handle. The last piece has a small ornamenting unit in the form a duck at its top side.

There is a fixed valve on the outer rim that has two hollow rings. Two pear-shaped units that are movable and in opposing positions are connected to it. Each unit has eight precise holes while the upper part has two protrusions, which come at the top side of the end of the tapering part of the handle fixed underneath the unit which is in the form of a duck on both sides. With these additions, the manufacturer manages to give the handle the shape of a dragon.

Contrary to the ornamentation of the valve which is dominated by concave style, the body is 
completely plain. A professional polishing will surely reveal the pattern of crucible steel. The lid of the wide nozzle of the horn's bottom is lost

\subsection{Plate (5)}

Type: Priming flask.

Material: Brass.

Dimensions: Length: $15 \mathrm{~cm}$.

\section{Registration number: 1671}

Production place: Persia (South East).
Technique: Casting, Soldering, Rivet

Weight: $156 \mathrm{~g}$.

Date: $19^{\text {th }}$ century $\mathrm{AD} / 13^{\text {th }}$ century $\mathrm{AH}$

Publication: First time.

Description: This priming flask is made of copper in the form of a crescent or a boat, with an inflating body in the middle tapering towards both sides. A valve closes the nozzle of the wide end which is fixed in the middle of the flask with rivets ending in a shape resembling a goose head. The other narrow end bends a little downwards and has no openings. Incision and carving styles are applied in ornamenting the whole surface of the priming flask with winding branches of plants holding leaves of three and five petals. The middle part of the body of the priming flask is an exception as it is decorated horizontally by three frames; the middle frame is a protruding line while the side frames are two undulant streaks.

\subsection{Plate (6)}

Type: powder flask.

Material: Wood, Iron ring Technique: Doming, Oil colours, Lacquer

Dimensions: Length:28cm., Diameter: $1.6 \mathrm{~cm}$., Thickness: $0.3 \mathrm{~cm}$. Weight: $321 \mathrm{~g}$.

\section{Registration number: $1704 \quad$ Date: $19^{\text {th }}$ century $\mathrm{AD} / 13^{\text {th }}$ century $\mathrm{AH}$}

Production place: Persia (Caucasus/North Persia). Publication: First time.

Description. This gunpowder flask is made of wood in the form of an oud or a mandolin. It consists of two parts; the lower one is in the form of half a pear, which has its flat side ornamented by a lobate decorative unit including an oval frame which has two persons drawn inside standing under a big tree, while the background is a natural scene showing a land with scattered green bushes and a sky in yellow combined with a light blue colour. The distribution of the components of the scenery demonstrates how the painter follows the rules of horizontal perspective. The two depicted persons wear similar clothes comprised of an open chest with an outer garment showing a shirt underneath. There is a wide scarf around the waist. While the man to the right puts on a cap, the other is wearing a turban, as well as a cloak on his shoulder. Their features have clear characteristics of the Qajar dynasty: the painter depicts the face in a three-quarter aspect, with a red cheek, a long nose, a tiny mouth, and almond-shaped eyes and thick eyebrows.

The painter's concern to depict them in their youth is highlighted in their full cheeks and shaved beard and moustache. He is also concerned with depicting them in conversation: having a dialogue and demonstrating interaction via hand gestures, as one of them is patting with his left hand the shoulder of the other while raising his right hand up to his face pointing with his forefinger. While the other man opens his right hand stretching it before him with his palm facing upwards while raising his left hand next to his chest. Winding plant branches and leaves and half-fan palm leaves surround the lobate unit. An iron ring is attached by nails at the top of the side's end.

- 143 - $\quad$ Persian Powder Flasks preserved in the Gayer- Anderson Museum in Cairo 
Recurring geometric decorations of distributed rhombuses made of bones in four columns cover the inflated side of the scenery as they have been carried out in inlaid style. Plant ornamentations dominate the space located between these two sides. It consists of branches and leaves covering the floor which are permeated by five geometrical units of different shapes. The main character of ornamentation of the geometrical units is an eight-petal flower which occasionally has little flowers connected to it. The in-between spaces are filled up with recurring paintings of a nightingale. The artist uses zigzag lines as a borderline between the inlaid part with bones and the plant ornaments in the other two parts.

The second upper section consists of a long rectangular neck which tapering upwards to end in a nozzle which does not have any lid. It has a plain surface except for the upper section which has a circular line of plant ornamentation similar to the previously mentioned, as it consists of branches, leaves and half-fan palm leaves of golden colour that has an eight-petal flower within.

The colours used in making the ornaments of that flask are generally characterized by diversity. Some of them are in different shades of red, dark green, light blue, turquoise, light brown, and a predominance of the golden yellow.

\subsection{Plate (7)}

Type: powder flask.

Material: Leather, Iron ring. Technique: Tanning, Sewing, Compression, Doming.

Dimensions: Length: $21 \mathrm{~cm}$, Diameter: $1.8 \mathrm{~cm}$, Thickness: $0.8 \mathrm{~cm}$. Weight: $143 \mathrm{~g}$.

Registration number: $1705 . \quad$ Date: 1875 AD/ 1292 AH.

Production place: Persia (Baluchistan or Sindh). Publication: First time.

Description: The flask is made of hardened leather comprising of two sections; the lower part is spherical with two inflated sides. A second part comes out of the first in the form of a long neck which ends in a nozzle closed by a lid. The lid consists of a small iron circle attached in the center by a circular ring, with a piece of leather covered piece of textile circling the post. A rectangular protrusion in the space following the two-part contact area attaches a circular ring to hang a leather strap. Meanwhile, the second part of the leather strap is tied to a ring behind the nozzle's lid.

Ornaments on the surface of the leather are incised with geometric and plant designs. The surface of the lower side has two main units whose ornaments are of plant branches sprouting from one source in the ground and ending in palm leaves. Three frames surround each unit which are characterized by a recurring element in the form of a triangle similar to the shape of arrowheads. This element is repetitively distributed in eight vertical lines on the neck of the powder flask, which are surrounded by two ribbons circling horizontally around the powder flask's neck from top and bottom. That is the main characteristic of their diagonal ornamentation lines which intersect vertically and horizontally.

The two groups of the previously mentioned three frames have the space in between occupied by a rectangular ribbon with an ornament of two big triangles in the middle whose heads face each other with a small rectangle between them. A foliage surmounts the triangles with the numbers 292 located underneath. There is an apparent cut instead of the fourth number. Supposing that these numbers stand for a date, then the missing number would be 1 . It is most probably that the manufacturing date of this powder flask is $1875 \mathrm{AD} / 1292 \mathrm{AH}$. 


\subsection{Plate (8)}

Type: Priming flask.

Material: Brass.

Technique: Moulding, Soldering, Rivet

Dimensions: Length: $26.5 \mathrm{~cm}$, Diameter: $1.3 \mathrm{~cm}$. Weight: $338 \mathrm{~g}$.

Registration number: 1706.

Date: $19^{\text {th }}$ century $\mathrm{AD} / 13^{\text {th }}$ century $\mathrm{AH}$.

Production place: Persia (South East).

Publication: First time.

Description: This priming flask is similar to the one with registration number 1671 (Pl. 5) in general design and ornaments. The only difference lies in size as it is the longer, wider, and heavier.

\subsection{Plate (9)}

Type: powder flask.

Material: Leather.

Technique: Tanning, Sewing, Compression, Doming

Dimensions: Length:28cm, Width:2.1cm, Thickness: $0.3 \mathrm{~cm}$. Weight: $169 \mathrm{~g}$.

Registration number: $1707 \quad$ Date: $19^{\text {th }}$ century AD/ $13^{\text {th }}$ century $\mathrm{AH}$

Production place: Persia (Baluchistan or Sindh). Publication: First time.

Description. This black powder flask is similar to the one holding the registration number 1705 (Pl. 7) in the overall design and ornaments' execution. It differs from the other black powder flask in leather colour and dimensions which increase a few centimeters in length and width. Another dissimilarity appears in the distributions of ornamentation elements that vary in form as well. The iron ring that is used for hanging the flask and the nozzle's lid are observed.

\subsection{Plate (10)}

Type: powder flask.

Material: Wood, Bones, Iron ring Technique: Cut, Inlaying

Dimensions: Length: $25 \mathrm{~cm}$, Diameter: $1 \mathrm{~cm}$, Thickness: $0.1 \mathrm{~cm}$. Weight: $162 \mathrm{~g}$.

Registration number: 1708

Date: $19^{\text {th }}$ century $\mathrm{AD} / 13^{\text {th }}$ century $\mathrm{AH}$

Production place: Persia (north Persia or Baluchistan or Sindh). Publication: First time.

Description. This black powder flask is made of two shaped and hollowed pieces of wood fixed together. The surface has been artificially treated to produce fiddle back pattern, a technique commonly used on gun stocks in Persia and the Caucasus. When natural striped maple is not available or a cheaper stock is required, string is wrapped round the stock and ignited. The burn marks create the same effect.

This powder flask looks similar to the two units carrying the registration numbers 1705 (Pl. 7) and 1707 (Pl. 9). Its surface is plain as the manufacturer relies on the natural colour of the wood and the marbling patterns of the covering bark except for adding three rectangular inlays, one of which circles around the lower edge of the inflated bottom of the flask; the second rectangular inlay meets up with the first on the other side, extending to the middle of the neck of the flask; and the third occupies the bottom of the neck inwardly. The general

145 - 1 Persian Powder Flasks preserved in the Gayer- Anderson Museum in Cairo 
embellishment of the three rectangular shapes is the application of bone inlay of recurring arrowhead units - or the Latin letter ' $\mathrm{V}$ ' - which are white interchanging with black colour. Each inlay begins and ends with one, two, or three small circles.

The black powder flask has a lid made from coloured textile that is tied to the neck by some thread. However, the strap for hanging the lid is missing.

\subsection{Plate (11)}

Type: powder flask.

Material: Wood, Bone, Iron Ring. Technique: Chiseling - Inlaying

Dimensions: Length: $18.5 \mathrm{~cm}$, Diameter: $0.9 \mathrm{~cm}$, Thickness: $0.3 \mathrm{~cm}$. Weight: $191 \mathrm{~g}$.

Registration number: 1709

Production place: Persia (Baluchistan).
Date: $19^{\text {th }}$ century $\mathrm{AD} / 13^{\text {th }}$ century $\mathrm{AH}$

Publication: First time.

Description. This black powder flask is similar to the previously mentioned one holding registration number 1704 ( $\mathrm{Pl}$. 6). It is made of wood on the form of oud or mandolin. It consists of two sections; the lower section is in the shape of half pear and the second is a relatively short neck. An iron ring protrudes from the surface of the straight side of the flask's bottom. This surface is plain which is unlike the rest of bottom's body and the neck, covered with inlays of bone in different shapes that are mostly dominated by rectangular and triangular shapes with long thin ribbons. They are distributed in order that a curved rectangular ribbon vertically goes through the middle of the spherical inflated body. Two pear-shaped spaces followed by two outwardly thin lines are located on both sides, while similar inlays circle around the neck. Shapes of small circles with black centers decorate the surface of those inlays using incision and carving. The black powder flask is missing its lid and hanging strap.

\subsection{Plate (12)}

Type: Priming flask.

Material: Copper, Gold. ${ }^{17}$

Technique: Moulding, Soldering, Rivet, Incision, Carving, Inlaying, Niello

Dimensions: Flask: Length: $15 \mathrm{~cm}$, Width: $9.5 \mathrm{~cm}$. Ribbon: Length: $90 \mathrm{~cm}$. Width: $1 \mathrm{~cm}$. Weight: $129 \mathrm{~g}$.

\section{Registration number: 1289 . Date: $19^{\text {th }}$ century AD/ $13^{\text {th }}$ century AH}

Production place: Persia

Publication: First time.

Description. The priming flask has the shape of a crescent or a boat with a similar design to the two objects carrying registration numbers 1761 (Pl. 5) and 1706 (Pl. 8). It has the same dimensions of the first priming flask with different ornamentation style. The carved surface is covered in groups of plants having eight-petal and six-petal flowers; four-petal perpendicular flowers occupy the space between them. Some spaces on the flask are covered

\footnotetext{
${ }^{17}$ It is regrettable that there is no chance to examine the steel used in inlaying as it requires executing some experimentations which are prohibited by law of the Egyptian Ministry of Antiquities. Hence, it was hypothesised that the inlaying material is gold based on characteristics of the colour, with a possibility that it could be gold flake or a golden painting that was used to give powder case the value of an inlaid antique.
} 
with gold inlay. Black niello is used to fill in hollow areas as well. The priming flask is carried by multi-coloured cords plaited to make a suspension sling.

\section{Analytic Study}

\subsection{Terminology}

Containers for gun powder are commonly known in English as 'powder horns' or 'powder flasks'. However, strictly speaking, the name 'flask' should be confined to those used for charge powder, as the smaller containers used for carrying finer powder to prime matchlocks, wheel-locks and flint-locks are called 'primers" ${ }^{18}$, "as the act of loading the muzzle with powder is called "primingk". ${ }^{19}$

Moreover, despite powder horn and powder flask are used interchangeably, it seems that not all powder flasks are powder horns - that depends on the used material.

The term 'powder horns' is used to refer to the first tool which has been specified to carry the powder used to load the muzzle. It has originally been taken from animal horns ${ }^{20}$ such as bulls, cows, gazelles, rams, narwhale, elephant tusks, etc. The hollow horn is cut from both sides and a lid or a capsule, usually made of metal, is put on both ends to hold the powder inside. To load the firearm, the lid should be removed from the small end of the horn and the powder is loaded into the muzzle. The flask was usually held above the shoulder or in a strap around the waist.

The meaning of the term 'powder horns' is, therefore, not all-inclusive for all types of containers specified for keeping the powder and loading the firearm's muzzle. These have witnessed some diversity that is hard to bring together and have taken special shapes in Eastern Islamic countries. Some of these powder flasks have taken the shape of horns while some others have taken shapes totally and partially different in style as they have been made of different raw materials and ornamented in all known methods that have been devised by talented artisans ${ }^{21}$.

Although Arabic studies have long adopted a literal translation for the English term "powder horn' as 'qorūn al-barūd قرون البارود', this study suggests to use the term 'حافظات أو حوافظ ' لورو' 'hauâfiz al-Barūd' as the signification of the term 'container' - correcting the term 'horn قرن' and its connotations - indicate maintenance and protection of the internal component, which suits the nature of black powder as an inflammable substance. In Arabic lexicons, to keep an object is to maintain, care, conserve, and retain it. A 'hāfiza حافظة' is a 'container' to hold papers in, and it is a file, a bag, or a pouch where papers, money and other items of sorts are kept in. The plural of 'hāfiza' is 'hauäfiz' for the inanimate ${ }^{22}$.

It should be noted that in relation to terminology, the word 'barutdan' is a Persian word ${ }^{23}$

\footnotetext{
${ }^{18}$ Allan and Gilmour, Persian Steel, p. 176.

${ }^{19}$ Stone, $\boldsymbol{A}$ Glossary of the Construction, p.515.

${ }^{20}$ We believe that the depicted symbol in the form of horn which appeared on the Mamluk composite blazon in the last third of the $15^{\text {th }}$ century $\mathrm{AD} / 9^{\text {th }}$ century $\mathrm{AH}$, when powder spread in using in firearms, is a natural horn of some animal. Its general form indicates that it has most probably been taken from an elephant's tooth. For this blazon, see: Ahmed, Al-Ranūk al-Islamiya, p.119.

${ }^{21}$ Stone, A Glossary of the Construction, Decoration and Use of Arms and Armor, p.515.

${ }^{22}$ Mujamm, al-Mu 'jam al-Wajīz, pp.160-161.

${ }^{23}$ The term "kebai barut" in The Great Persian Lexicon denotes "powder quiver". There is also "barut hāanh" which signifies "powder depot". Shitá, Al-Mu'jam Al-Farsi al-Kabīr, pp. 263-2070. In Persian lexicons, the term powder or "barūt" is defined as an Arabization of the term "bārūd" while the Iraqi tradition considers it as wall salt which grows on ancient walls and Iraqis gather. It is piquant and sharper in taste than salt that clears
}

- 147 - $\quad$ Persian Powder Flasks preserved in the Gayer- Anderson Museum in Cairo 
which linguistically signifies a flask made of metal, wood, animal horns, or leather which has been used to hold black powder for guns. ${ }^{24}$

\subsection{Types ${ }^{25}$ of Powder and priming Flasks}

Powder and priming flasks studied in this paper have been formed in different artistic types, and can be divided into four main types:

\subsubsection{Type A}

The first type, the flasks are shaped in the form of animal horns ${ }^{26}$ (Pls. 1-4) noting that it has two shapes; the first shape has a curved cylinder shape (Pl.no.1, Fig.no.1), with the examples of a green ivory horn available for sale on Oriental-Arms website with number 10696. It is attributed to Persia during the $18^{\text {th }}$ or $19^{\text {th }}$ century $\mathrm{AD} / 12^{\text {th }}$ or $13^{\text {th }}$ century $\mathrm{AH}(\mathrm{Pl} .13) .^{27}$

The second shape is much more curved (Pls.nos.2/3/4) (Fig.no.2) and smaller in body ratio than the earlier one. It is the most common type in the Persian history. Some of its wellknown examples are five priming flasks preserved in Parviz Tanavoli collection, of which four are made of steel ${ }^{28}$ while the fifth is made of wood with metal fittings. Some other five priming flasks have been mentioned by George Cameron Stone in his book on arms and armour. They are made of different materials such as bronze, wood with bronze fittings, steel inlaid with gold, ivory with steel revetments, and black horn with a bone end. ${ }^{29}$

Brooklyn Museum possesses a Priming flask of this shape which is made of steel. It is attributed to Persia during the $18^{\text {th }}$ or $19^{\text {th }}$ century $\mathrm{AD} / 12^{\text {th }}$ or $13^{\text {th }}$ century $\mathrm{AH}$ with register number 18.178.1 and its length is $14 \mathrm{~cm} .{ }^{30}$

The Ethnographic Museum in Tehran keeps two Priming flasks dating to the $19^{\text {th }}$ century $\mathrm{AD} / 13^{\text {th }}$ century $\mathrm{AH}$ Persia. The first flask is made of brass with coral paste and glass fittings with registration number 4280 , and its measurements are $18 \times 4 \mathrm{~cm}$. It is distinguished by ornamentations including plant and animal elements, and the remnants of enamel. The other flask is $13.2 \mathrm{~cm}$ and made of steel and copper. It is preserved under number $4279 .{ }^{31}$ Arms and Antiques website puts up for sale a Priming flask of this shape with registration number ma424. It is made of steel and dated to the $18^{\text {th }}-19^{\text {th }}$ century AD/ $12^{\text {th }}-13^{\text {th }}$ century AH Persia. It is distinguished with its valve's open work ornament. The end of the flask has

stomach from body toxics. The powder is used in work which needs fire so that it can increase flames fast. It is only Iraqis who use that powder in medicine. Altungi, $\mathbf{M u}$ 'jam al-Mu'rrabāt al-Farisiyah, pp20-21.

${ }^{24}$ Khorasani, Lexicon of Arms and Armor from Iran, p. 114.

${ }^{25}$ Artistic types of Islamic powder cases vary in a manner that is hard to estimate, which requires a major extended study to gather and categorise these types. There are other types, in addition to the ones enlisted in this study, of which ones taking the form of sea shells, water flasks, and some fruits. While some cases are formed in shape of birds and animals or mythical creatures, others take shapes of different types of fish and other different shapes.

${ }^{26}$ This type is not exclusive to Persia as it spreads in other Islamic regions. Some of its best example attributed to India and one of them is traced back to Deccan and preserved in the Metropolitan Museum with registration number 2009.469 (P1.no.14). It was made of ivory, bone, gold, silver, copper, iron, and it was coloured and lacquered. The Museum dates it to the $17^{\text {th }}$ century AD/ $11^{\text {th }}$ century AH with dimensions of $20 \times 19.7 \mathrm{~cm}$. and weight of 576 g. http://www.metmuseum.org/art/collection/search/35674 (accessed 3 Aug. 2016).

${ }^{27} \mathrm{http}: / /$ www.oriental-arms.co.il/item.php?id=4389 (accessed 4 Aug. 2016).

${ }_{28}^{28}$ For more details, see: Allan (James) and Gilmour, Persian Steel, p.178, fig.A.23-A.27.

${ }^{29}$ Refer to: Stone, A Glossary of the Construction, Decoration and Use of Arms and Armor, p.516, fig.660,1, $2,5,10,19$.

${ }^{30}$ https://www.brooklynmuseum.org/opencollection/objects/10535 (accessed 6 Aug. 2016).

${ }^{31}$ Kelényiand Szántó, Artisans at the Crossroads, pl. c.3.2.55., c.3.2.56. 
shaped in a bird's head ${ }^{32}(\mathrm{Pl}$. 14). It corresponds in shape with the flask published in this study with registration number $1667(\mathrm{Pl} .4)$.

It is worthy noted that this pattern ${ }^{33}$ appeared among Persian artistic painting elements since the Safavid era. There is a painting preserved in Freer Gallery depicting "Bandits Attacking the Caravan of Aynie and Ria" from the manuscript Haft Awrang or The Seven Thrones by Jami which was written and illustrated under the patronage of Prince Ibrahim Mirza during the period from 1556 to $1565 \mathrm{AD} / 963$ to $973 \mathrm{~A}$.H. It represents a person in the upper section of the painting holding a rifle in his right hand, there is a Priming flask is hanging from his belt, it is in the form of a curved horn ${ }^{34}(\mathrm{Pl} .15){ }^{35}$

There are two paintings made by Habib Allah of Mashad ${ }^{36}$ during the reign of Shāh Abbās I (1587-1629 AD/ 996-1038 AH). The first painting is preserved in the library of Topkapi Palace Museum in Istanbul depicting "Youth Loading a Matchlock" in which a priming flask taking the form of a winding horn ${ }^{37}$ is hung on waistband. The second painting depicts "A Musketeer" (P1. 16), one of the tofangččs or Persian Musketeer, preserved in the Museum of Islamic Arts in the Berlin State Museum. The painting portrays a musketeer holding handle of the rifle resting on his shoulder in a way that highlights the long barrel behind his head, while carrying a priming flask on the right side of the waist that takes the shape of a winding horn as well ${ }^{38}$.

The same painting style of that musketeer can be repeatedly noticed in part of a stone carving of the Fath Ali Shāh Qajar. It shows the Shah hunting gazelles in company of some of his sons and statesmen in Firuz-kuh, located to the northeast of Tehran, that dates to 1817 1818AD/ $1233 \mathrm{AH}^{39}$ (Pl. 17). It is distinguished by a different shape of the powder horn in comparison to the powder horn in the previous painting.

This type is considered the oldest shape used to preserve the powder as was previously mentioned.

\subsubsection{Type B}

In this type, flasks are in the form of a crescent ending with a bow downwards at one end (Pls. 5, 8, 12) (Fig. 3). This makes the shape closer to boats depicted in Persian manuscripts

32 http://armsandantiques.com/18th-c-persian-safavid-black-wootz-powder-flask-ma424 (accessed 4 Aug. 2016).

${ }^{33}$ There are historical references which demonstrate that powder was carried in animal horns. One of the reference is a record from the reign of Nāder Shāh Afshār explaining that most of his regular army carried the Flintlock rifles and that they kept the powder in cases of animal horn shape; the horns helped them measure the powder and control the range of the bullets. Farrokh, Iran at War: 1500-1988, p. 92.

${ }^{34}$ The shape of the horn is not new to the Persians; it was well-known during the Sasanian era as a drinking cup and often made of precious metals, especially silver inlaid with gold, for example, there is a silver drinking cup in a horn shape is preserved in the Arthur M. Sackler Collection which dates to $4^{\text {th }}$ century AD. The cup is 14.2 $\mathrm{cm}$ in diameter and weighs 598.5g. Harper, The Royal Hunter Art of the Sasanian Empire, pp. 36-37, Plate 5.

${ }^{35}$ The folio number is $64 \mathrm{~b}$, and the measurements are $27.9 \times 18.2 \mathrm{~cm}$. Simpson (Marianna Shreve), Persian Poetry, Painting and Patronage, p. 30.

${ }^{36}$ For detailed information about this painter and his prominent works, see: Swietochowski, Habib Allah, pp. 283-299; http://www.iranicaonline.org/articles/habib-allah-savaji; and http://rch.ac.ir/article/Details?id=9440 (accessed 5 Aug. 2016).

${ }^{37}$ Swietochowski, Habib Allah, p.284, p1.2.

${ }^{38}$ Elgood, Firearms of the Islamic World, p.113.; Matthee, Firearms in Persia, p.621, pl.II.; and http://www.iranicaonline.org/uploads/files/firearms i pl3.jpg (accessed 1 Aug. 2016).

${ }^{39}$ Luft, The Qajar Rock Reliefs, p.32, pl.1.; Scarce, Ancestral Themes in the Art of Qajar Iran 1785-1925, p.4237.

149 - $\quad$ Persian Powder Flasks preserved in the Gayer- Anderson Museum in Cairo 
paintings which show the bow of some boats ending with a curve downwards, sometimes shaped in the form of a dragon's head or a goose. An example of this is a painting by Shaikh Zada entitled "Alexander Hunting Ducks in a Voyage" from Mìr 'Ali shernavai's manuscript which dates to $1525 \mathrm{AD} / 931 \mathrm{AH}$, kept in the National Library of France. Another painting depicts "Arrival of a Prince and Princess in Paradise Island" from Haft Awrang manuscript which dates to 1556-1565 AD/ 963-974 AH. The painting is kept in Freer Gallery of Art in Washington.

Many examples with this crescent shape are attributed to Persia or India from different historical periods, perhaps, some of them are copied or have had the general form replicated to the extent that it is difficult to determine their production place due to the similarity in the general design in both countries. Thus, ornamentation elements and their execution, along with the source of acquiring the object, play a role in accurately determining its manufacturing center. It is noticeable that most of this published type are attributed to Persia for example, two powder flasks which George Cameron Stone mentioned in his book on weapons and armours. The first is made of copper inlaid with silver, and the second is made of carved copper ${ }^{40}$. Christies Auction House website displays item number Sale 5744 Lot 241 which is similar to this shape in its general form. Its highest length is $25 \mathrm{~cm}$ and is made of yellow copper and steel. The website attributes the item to Persia in the $18^{\text {th }}$ century AD/ $12^{\text {th }}$ century AH. ${ }^{41}$

The samples in this study of this shape (Pls. 5, 8, 12) are very similar to, if not identical with, the two samples which George Cameron Stone refers to in his book on weapons and arms, thus confirming their attribution to Persia.

\subsubsection{Type C}

This type is a black powder flask in the shape of an oud or a mandolin (Pls. 6, 11) (Fig. 4). This type is quite rare. It is a very rare form. An exceptional example is a black powder flask offered for sale in Urgrbbitr Antiques website among the Istalifi Collection, made of wood and the surface inlaid with shells, while the neck is ornamented by bone. The dimensions of the flask are $17 \times 7.5 \mathrm{~cm}$. and attributed to North Africa in the $18^{\text {th }} \mathrm{AD} / 12^{\text {th }}$ century $\mathrm{AH} .^{42}$ Although this might cause some doubt regarding the attribution of the two studied flasks to Persia, that does not hold against archaeological evidences; for the black powder flask with registration number 1704 (Pl.no.6) (fig.no.4) is decorated in lacquer style which corresponds to the Persian lacquer work decoration. Additionally, the painting on the black powder flask shows two Sufis in the Qajar style. Their facial expressions show Qajar features. Moreover, Qibaa which is the type of the garment that the persons are wearing correspond to the Qajar style garment.

Accordingly, the other flask with a registration number 1709 (P1. 11) can be attributed to Persia. It is very similar to the previous flask, and the technique of inlaid bone was common among black powder flask production in Persia, in terms of row material, elements, or artistic design since the mid of the $19^{\text {th }}$ century AD/ $13^{\text {th }}$ century AH.

\footnotetext{
${ }^{40}$ Stone, $\boldsymbol{A}$ Glossary of the Construction, p.516, fig. $660,3,6$. http://www.christies.com/lotfinder/arms-armor/a-large-steel-and-brass-powder-horn-5422471-details.aspx (accessed 30 July 2016).

${ }^{42}$ An ascription is dubious due to lack of evidence. However, the flask can most probably be ascribed to the $19^{\text {th }}$ century $\mathrm{AD} / 13^{\text {th }}$ century $\mathrm{AH}$ Persia based on two models published in this study $(\mathrm{Pls}$. 7,12). https://rugrabbit.com/node/140845 (accessed 24 Aug. 2016).
} 


\subsubsection{Type D}

This type mainly uses leather in forming the black powder flask. Its artistic design consists of an inflated spherical body connected to a neck which slops downwards (Pls. 7, 9, 10) (Fig. 6). It can be divided into two shapes: the first is completely made of hardened leather in the same pattern used in manufacturing baseballs (Pls. 7, 9; Fig. 5), while the second has a wooden body (Pl. 10).

Examples for the first type are some black powder flasks offered in auctions houses, mainly made of camel leather. Their country of origin is Afghanistan as they were spreading among Afghani tribes, which makes it probable that they could be attributed to Persia, specifically to the eastern origins, as Afghanistan was part of Iran before separation.

One of the best samples of this flask is offered for sale in Arms and Antiques website with number mf452 and is attributed to Persia in the $19^{\text {th }}$ century AD/ $13^{\text {th }}$ century AH. Its surface is characterized by inscriptions in Arabic and Persian languages ${ }^{43}$, including the name of its producer "Mohamed", and pictorial scenes of a lion clawing the back of a bull in the same manner of the Qajar painting (Pl. 18) ${ }^{44}$. Furthermore, there is another example of this shape on Oriental Arms website with number $14081(20 \mathrm{~cm}$. height $)$. It is similar to the flask in this study with registration number 1705 (P1. 7) regarding the plant ornamentation and dates to $1869 \mathrm{AD} / 1286 \mathrm{AH}^{45}$. Another similar black powder flask on the same website with number 13438 and is characterized by its relatively big size $(30.5 \mathrm{~cm}$. height). The surface is decorated with plant ornaments permeated with two central units occupied by a preying theme of a lion attacking a bull. ${ }^{46}$

There is another sample preserved in the Pyotr Ivanovich Shchukin Collection -a Russian art collector and the founder of Shchukin Museum - with number No.1424 II. This sample is made of leather and ornamented with lacquer $(23.5 \times 9 \mathrm{~cm}$.). Iran could be the origin of production, and it dates to $19^{\text {th }}$ century $\mathrm{AD} / 13^{\text {th }}$ century $\mathrm{AH}$, according to the name of the artisan Ali Akbar, ${ }^{47}$ which is recorded on the flask's neck, besides, the date of $1870 \mathrm{AD} /$ $1287 \mathrm{AH}$. It has several decorations of plants, branches, leaves, and flowers on which birds stand. Additionally, there is a pictorial scene of a lion attacking a bull (Pl. 19). ${ }^{48}$

\footnotetext{
${ }^{43}$ On presenting images of these cases on some specialists in Eastern languages, they stated that the writings on the powder cases combine both Arabic and Persian languages. They add that letter "fa",, whose correspondent in English is " $\mathrm{f}$ ", is surmounted with three dots as it is common in Kurdish language. Moreover, they ascribe the case to a Kurdish territory governed by Persia when the Kurdish Language mixed with Arabic and Persian. Kurdish is one of the Persian languages which represents Indo-European languages. Kurdish language embraces many terms from Arabic and Persian, and some terms from Turkish. These terms were used in media and newspapers in Iran before they were banned for political reasons. For further details on Kurdish language, see: Taj, Al-Akrād Tarīkh Sha'b wa-Qaḍiyat Wațan, pp. 57 - 68; Hușāf, Kordistān wa-al-Mas'alah alKordiyah, p.89-91; Muhammad, Akrād al-Irāq tah̆t Hokm abd-al-Karīm Qasim, p.53-58.; http://www.iranicaonline.org/articles/kurdish-language-i; http://cabinet.gov.krd/p/p.aspx?1=14\&s=020000\&r=353\&p=254 (accessed 24 Sep. 2016).

${ }^{44} \mathrm{http}$ ://armsandantiques.com/19th-c-persian-gunpowder-flask-mf452 (accessed 5 Aug. 2016).

45 http://oriental-arms.co.il/item.php?id=4180 (accessed 5 Aug. 2016).

46 http://www.oriental-arms.com/item.php?id=6800 (accessed 5 Aug. 2016).

47 According to Sarmadi, there are many artists on the Qajar period who was called "Ali Akbar", so it is difficult to identify which one of them is meant on this powder case. For more information about Ali Akbar see: Sarmadi, An Encyclopedia of the Artists in Iran, pp. 436-437.

${ }^{48}$ This case was in the possession of a Persian antiques collector until 1927 when it has moved to the possession of a Russian antiques collector. It was first published in the book, Iranian Lacquer Work in the State Museum of Oriental Art. For further details, see: Sazonova, Iranian Lacquer Work in the State Museum of Oriental Art, p.268, pl.117.
}

- 151 - Persian Powder Flasks preserved in the Gayer- Anderson Museum in Cairo 
The second shape uses different material. For instance, there is a powder flask in the Metropolitan Museum in New York with number 36.25.2338, which is made of wood, brass, bone, and leather. Its dimensions are $29.9 \times 9.5 \mathrm{~cm} ., 306.2 \mathrm{~g}$, and is attributed to Persia in the $19^{\text {th }} \mathrm{AD} / 13^{\text {th }}$ century $\mathrm{AH}(\mathrm{Pl} .20){ }^{49}$

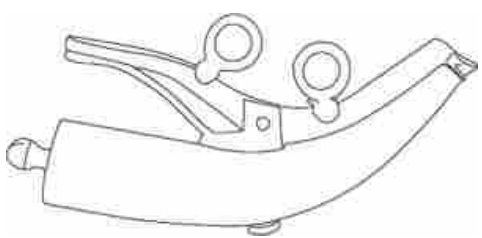

4 fig.1: Type A, First shaped.

fig.2: Type A, Second shaped.
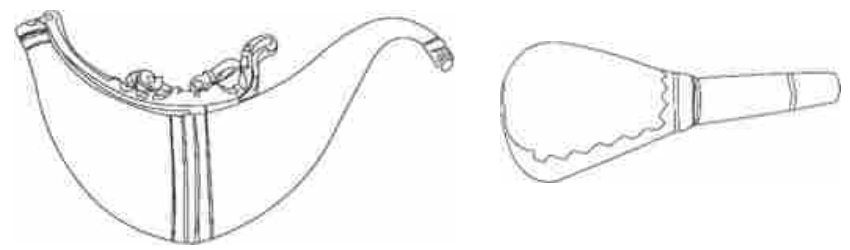

fig.no.4: Type C.

fig.no. 3: Type B.
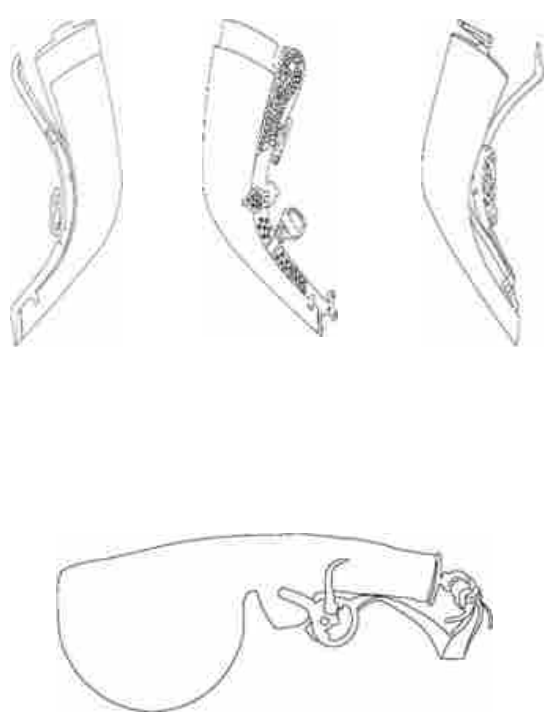

fig.no.5: Type D.

\subsection{The Relationship between Form and Function}

It is noticeable that early powder flasks take the shape of animal horns for they are the most suitable form for its function to prevent any one to have access to its content to ignite the powder. Animal horns, by nature, neither catch on fires nor are flammable material. Moreover, their friction against other materials does not result in a spark of any sort. The same can be also applied to other wooden flasks, except for the ivory which has an advantage over wood in having a smooth pore-free surface which prevents powder from permeating into the flask's structure. Therefore, manufacturers have often resorted to processing the internal surface of wood flasks to avoid permeation.

Some of the objects of this study have been supplied with two functional nozzles (Pls. 1, 4). The first nozzle is wide with the purpose of filling in gunpowder easily. The second nozzle is narrow to control the amount of powder used to load the firearm. In addition, the flask's narrow nozzle is smaller diameter than the firearm's muzzle and pans of firearms, which allows to go inside to maximize the reduction of the amount of waste powder during loading. The nozzle's lid is wide in size so that it can be fixed in its position by pressing it down (Pl.4) or spirally (Pls. 1, 3). This lid sometimes has a small ring in the middle (Pls. 2, 3) or a small projection in the form of a handle to be easier to hold (Pl. 1).

\footnotetext{
${ }^{49}$ It should be noted that the museum ascribes this powder case to India without documenting reasons. This is incorrect because the comparative study uncovers that the artistic design of this pattern is purely Persian. Furthermore, the inlaying technique used in ornamentation is different from the one commonly used in India, while matches the Persian methods. http://www.metmuseum.org/art/collection/search/30438 (accessed 5 Aug. 2016).
} 
Most priming flasks (Pls. 1, 2, 3, 4, 5, 8, 12) are supplied with a spring valve to open the nozzle quickly as soon as it is pressed with the thumb, and to close when the pressure of the thumb is removed. The presence of such a valve ceases the probability of leaving the nozzle open.

It was the custom to attach one or more hollow steel rings to the body of these flasks to pass a ribbon, a chain, or a thick string through them, which help to hang the black powder flask to a belt for the holder or to hang it on the shoulder or even the neck. The artistic design of the third and fourth types, which include a spherical bottom, has a functional value represented in using the fist of the hand holding the flask, which is one of the strongest positions of the human hand to hold items as the whole of the internal surface of the hand dominates the spherical or the cylindrical body. In this position, most parts of the palm- or its whole - are in direct contact with the held item, which is the bottom of the flask, that allows better control over the powder flask and pouring the powder.

The following table shows that the average weight of powder flasks upon which the study was conducted reaches 191.5 grams, which is not a source of heft on human hand. The study also found that the average height for the flasks is $19.6 \mathrm{~cm}$. Since the average human hand is $19 \mathrm{~cm}^{50}$, we can conclude that flask's height average suits the human hand. This allows the biggest part of the flask to settle in the palm, while the narrowest nozzle within the reach of the fingers to ease it for the thumb and the index to hold and incline it to have the powder inside. Moreover, the little thickness of the lower part which ends in a nozzle in all flasks allows having a tight control of the palm of one hand during loading the powder while the other hand holds the firearm's muzzle or the pans of wheel-lock firearms.

\begin{tabular}{|l|c|c|c|c|c|c|c|c|c|c|c|c|c|}
\hline Plate Number & 1 & 2 & 3 & 4 & 5 & 6 & 7 & 8 & 9 & 10 & 11 & 12 & Average \\
\hline Height c m . & 17.5 & 12 & 14 & 15 & 15 & 28 & 21 & 26.5 & 28 & 25 & 18.5 & 15 & 19.6 \\
\hline Wight in Grams & 264 & 95 & 164 & 167 & 156 & 321 & 143 & 338 & 169 & 162 & 191 & 129 & 191.5 \\
\hline
\end{tabular}

Table (1) The average of the height and weight of the group of powder and priming flasks in this paper

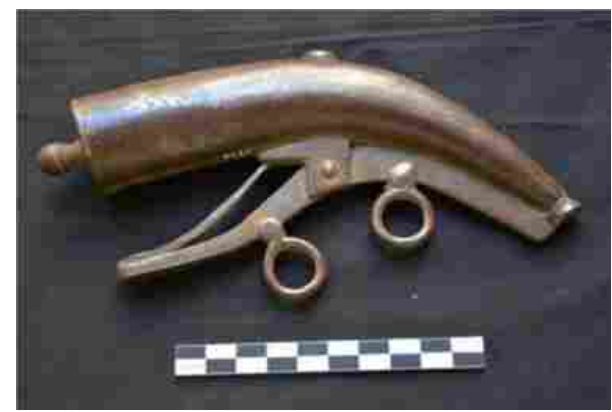

Pl. 1

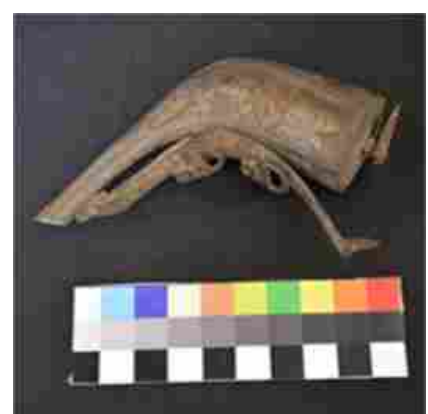

Pl. 2

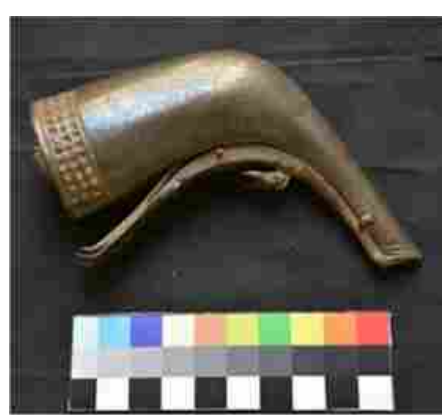

Pl. 3

P1. 1: Priming flask made of crucible steel, Persia (Iran), $19^{\text {th }}$ century AD/ $13^{\text {th }}$ century $A H$, GayerAnderson Museum in Cairo, registration number 1663.

Pl. 2: Priming flask made of crucible steel, Persia (Iran), $19^{\text {th }}$ century $\mathrm{AD} / 13^{\text {th }}$ century $\mathrm{AH}$, GayerAnderson Museum in Cairo, registration number 1664.

Pl. 3: Priming flask made of crucible steel, Persia (Iran), $19^{\text {th }}$ century AD/ $13^{\text {th }}$ century AH, GayerAnderson Museum, registration number 1666.

\footnotetext{
${ }^{50}$ Ibeachu, Abu and Didia, Anthropometric Sexual Dimorphism of Hand Length, p.146.
}

- 153 - Persian Powder Flasks preserved in the Gayer- Anderson Museum in Cairo 


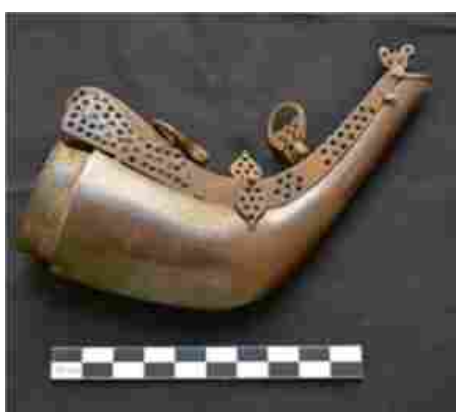

Pl. 4

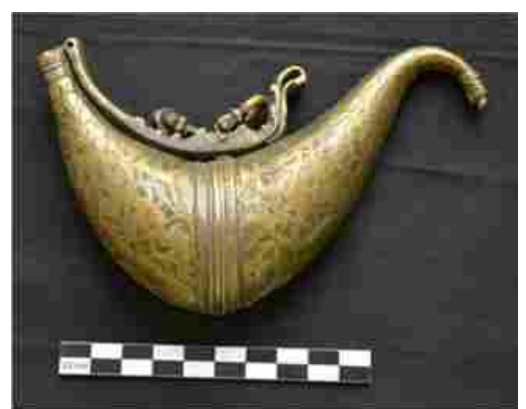

Pl. 5

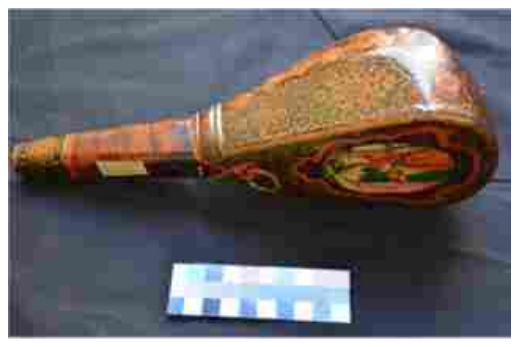

Pl. 6

Pl.no. 4: Priming flask made of crucible steel, Persia (Iran), $19^{\text {th }}$ century AD/ $13^{\text {th }}$ century AH, GayerAnderson Museum, registration number 1667

Pl.no. 5: Brass priming flask, Persia (Iran), $19^{\text {th }}$ century AD/ $13^{\text {th }}$ century AH, Gayer-Anderson Museum, registration number 1671.

Pl.no. 5 Bone inlaid wooden black powder flask ornamented with lacquer work, Persia (Iran), $19^{\text {th }}$ century $\mathrm{AD} / 13^{\text {th }}$ century $\mathrm{AH}$, Gayer-Anderson Museum, registration number 1704.

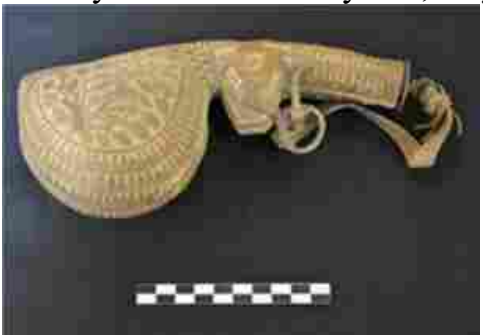

Pl. 7

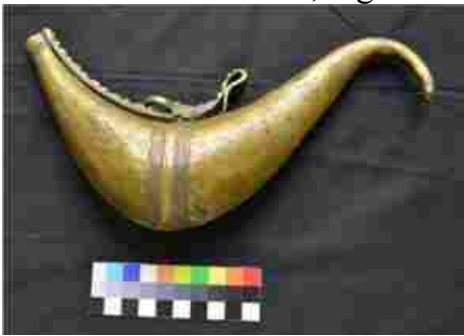

Pl. 8

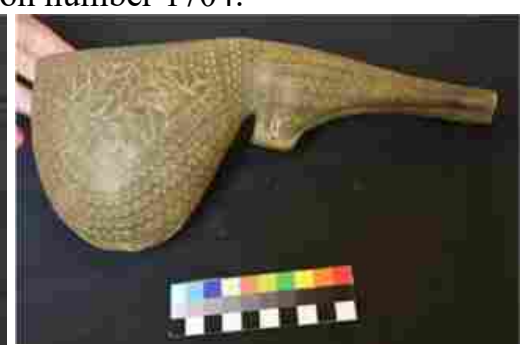

Pl. 9

Pl. 7: Black powder flask made of leather, Persia (Iran), $19^{\text {th }}$ century AD/ $13^{\text {th }}$ century AH, GayerAnderson Museum, registration number 1705.

Pl. 8: Copper priming flask, Persia (Iran), $19^{\text {th }}$ century AD/ $13^{\text {th }}$ century AH, Gayer-Anderson Museum, registration number 1706.

Pl. 9 Leather black powder flask, Persia (Iran), $19^{\text {th }}$ century AD/ $13^{\text {th }}$ century AH, Gayer-Anderson Museum, registration number 1707.

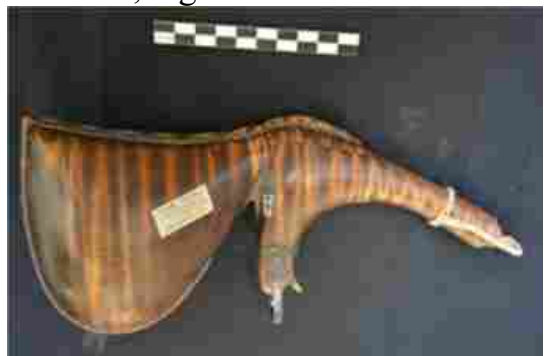

Pl. 10

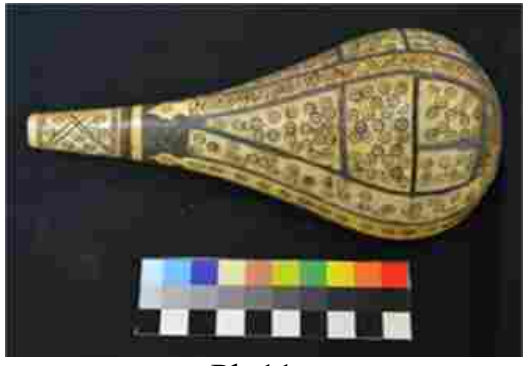

Pl. 11

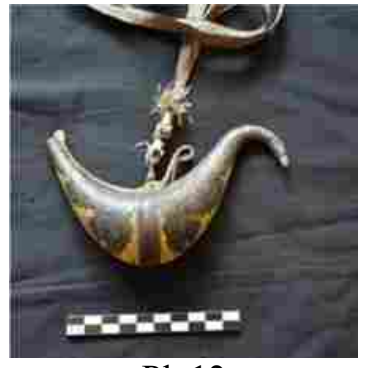

Pl. 12

Pl.10: Bone inlaid wood blackpowder flask, Persia (Iran), $19^{\text {th }}$ century AD/ $13^{\text {th }}$ century AH, GayerAnderson Museum, registration number 1708.

Pl. 11: Bone inlaid wood black powder flask, Persia (Iran), $19^{\text {th }}$ century AD/ $13^{\text {th }}$ century AH, Gayer-Anderson Museum, registration number 1709.

Pl. 12: Gold inlaid copper priming flask, Persia (Iran), $19^{\text {th }}$ century AD/ $13^{\text {th }}$ century AH, GayerAnderson Museum, registration number 1289. 


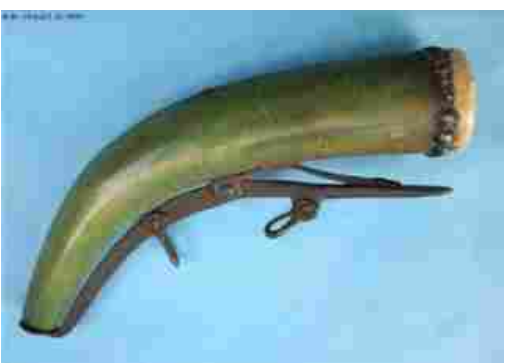

Pl. 13

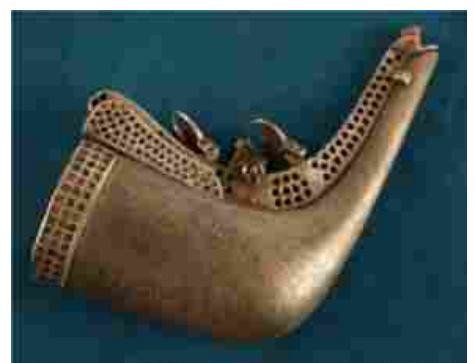

Pl. 14

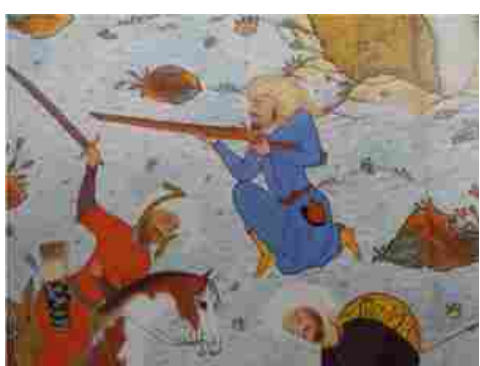

Pl. 15

Pl. 13: Green-dyed walrus ivory priming flask, Persia, $18^{\text {th }}$ or $19^{\text {th }}$ century $\mathrm{AD} / 12^{\text {th }}$ or $13^{\text {th }}$ century AH, dispalyed for sale in Oriental-arms website with number 10696. Source: http://www.orientalarms.co.il/item.php?id $=4389$

Pl. 14: Priming flask, Persia (Iran), $18^{\text {th }}$ or $19^{\text {th }}$ century AD/ $12^{\text {th }}$ or $13^{\text {th }}$ century AH, displayed for sale on Arms and Antiques website with number ma424. Source: http://armsandantiques.com/18th-cpersian-safavid-black-wootz-powder-flask-ma424

Pl.no. 15: "Bandits Attacking the Caravan of Aynie and Ria", Haft Awrang manuscript, Persia, 15561565 AD/ 963-973 AH, in the Freer Gallery of Art exhibition. Source: Marianna Shreve Simpson, Persian Poetry, Painting and Patronage, pp: 30.

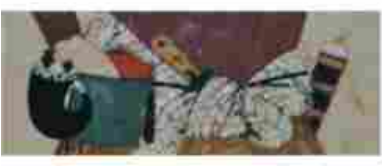

Pl. 16

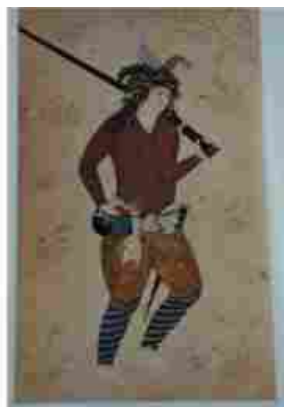

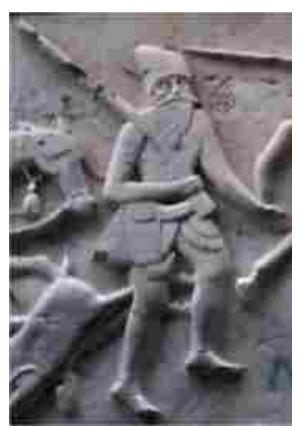

Pl. 17

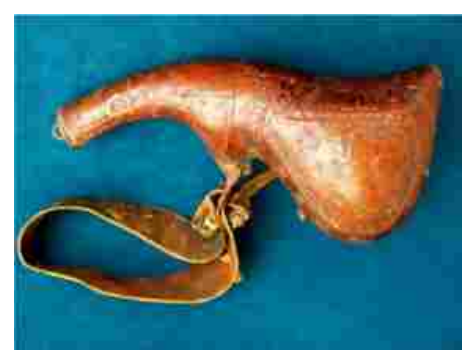

Pl. 18

Pl. 16: Depiction of a musketeer with a gunpowder flask hanging from his belt during the reign of Shāh Abbās I of Persia (Iran), 1587-1629 AD/ 996-1038 AH, artist Habib Allah of Mashad.

Source: Matthee (Rudi), "Firearms in Persia", pp:621, pl.II.; http://www.iranicaonline.org/uploads/files/firearms_i_pl3.jpg

P1. 17: Part of the relief of Fath-Ali Shāh Qajar hunting in company of some of his sons and statesmen in Firuz-kuh, located to the Northeast of Tehran, 1817-1818 AD/ 1232-1233 AH. Source: Luft, Paul. The Qajar Rock Reliefs, pl.1.

Pl. 18: Leather blackpowder flask, Persia (Iran), $19^{\text {th }}$ century AD/ $13^{\text {th }}$ century $\mathrm{AH}$, dispalyed for sale on Arms and Antiques website with number mf452.

Source: http://armsandantiques.com/19th-c-persian-gunpowder-flask-mf452

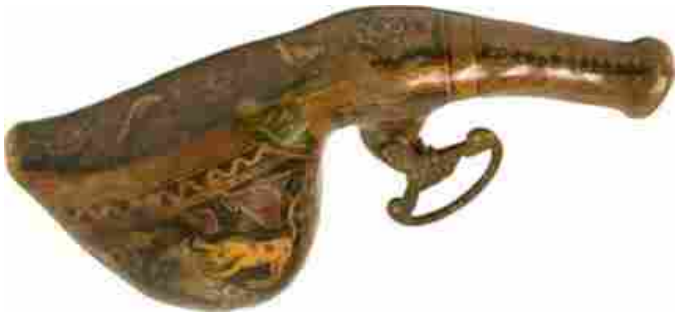

Pl. 19

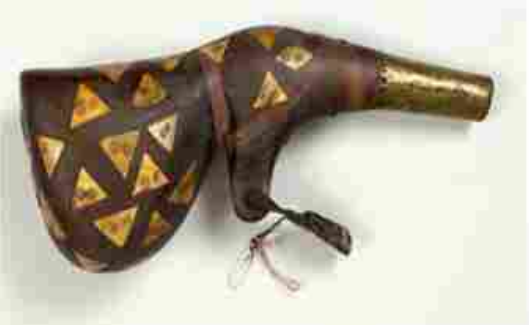

Pl. 20

Pl. 19: Leather/hide black powder flask ornamented with lacquer work, Persia (Iran), 1870 AD/ 1287 AH, with the name of Ali Akbar, preserved in the Pyotr Ivanovich Shchukin (Пётр Иванович Щукин) collection, with number No.1424 II. Source: Natalia Sazonova, Iranian Lacquer, p.268, pl.117.

P1. 20: Black powder flask made of Brass, wood, bone, leather, Persia (Iran), $19^{\text {th }}$ century $\mathrm{AD} / 13^{\text {th }}$ century AH, in the Metropolitan Museum, registration number 36.25.2338.

Source: http://www.metmuseum.org/art/collection/search/30438

- 155 - $\mid$ Persian Powder Flasks preserved in the Gayer- Anderson Museum in Cairo 


\section{Conclusion}

This study represents a new addition to the Persian powder and priming flasks collections which are different from other type of flasks in form and quality. This might help - with the continuity of publishing new antiquities - to form a comprehensive perception on the manufacturing and ornamentation of this type of Persian artefacts.

Essentially, the study analyzed and categorized twelve flasks of the collection of GayerAnderson Museum into four artistic types: The first type is in the form of animal horns; the second type takes the form of a crescent; the third type has the shape of oud or mandolin musical instruments; and the fourth type has a spherical body connected to its neck.

Regarding the fourth type it depended on the skin of male camel's genitals to make powder flasks. This reflects their attachment to tribal culture which has dominated the life there since the $18^{\text {th }}$ century $\mathrm{AD} / 12^{\text {th }} \mathrm{AH}$ century with the emergence of the Afsharid dynasty. It also reflects their engagement of these natural elements to the extent that they used some of their characteristics in producing and developing modern equipment and tools such as powder flasks.

For example, the first type of the early manufacturing of powder flasks have been inspired by the shape of animal horns. Making the first type involves mainly using metals, steel, bronze, and copper specifically with respect to the capability of these metals', their durability and resistance to fracture, which match the nature of military needs and combats. As firearms moved to hunting sports, shapes of these flasks varied as well as the raw materials which were used to make them which suit the nature of black powder to the extent that the flasks were created by papier-mâché ${ }^{51}$. This confirms the capability of manufacturers to master all types of raw materials and ornamenting and manufacturing techniques prevailing in the $19^{\text {th }}$ century $\mathrm{AD} / 13^{\text {th }}$ century $\mathrm{AH}$ according to purchasing power of the buyer and nature of application.

Another example is the manufacturing style of the second shape of the fourth type relies on a wood mould with dimensions simulating that of the camel's - or other animals' - phallus. This type draws interest which demonstrates our need to conduct an independent and extended research to assess all aspects and elements related to it, particularly the geographical distribution, reasons and symbolism. It can be initially noted that this shape has spread among the tribal communities in East of Persia, especially, the Baluch who overran Sindh in the late $18^{\text {th }}$ century $\mathrm{AD} / 12^{\text {th }}$ century $\mathrm{AH}$ and established states. It can also be noted the earliest samples of this type have used leather of male camel's genitals for reasons which relate to the importance of camels and phallic symbolism in the culture of these tribes. Furthermore, there is a perceived connection in many societies between gunpowder and male sexuality making powder flask (barutdan) particularly appropriate.

During the Islamic age, manufacturers paid attention to the functional side of their products. In the meantime, they have sought to decrease accidents ratio to the minimum, particularly when related to weapons and ammunition, one of which is powder flasks. This was reflected on the course of historical events in which there is no reference to explosions when using powder flasks in loading firearms, unlike what circulated in Europe.

51 The Metropolitan in New York preserves a powder case with preservation number " 32.25 .2429 " which is made of papier-mâché with the dimensions $17.2 \times 15.2 \times 10.5$ in centimetres. It weighs 331.7 grams and ascribes to the $\mathrm{AD} 18$ th or 19th/ $\mathrm{AH} 12$ th or 13th century. http://www.metmuseum.org/art/collection/search/30366 (accessed 1 Aug. 2016).

Persian Powder Flasks preserved in the Gayer- Anderson Museum in Cairo - 156 - 
Another point concerning the origin of the Islamic powder flasks, as the larger number of them has been ascribed to India during the reign of Mughal emperors according to what was mentioned by some researchers regarding this matter ${ }^{52}$. Persia falls in the second place which can be attributed to the relatively slow update of armed forces that has led to relying upon the very first editions of firearms that are based upon manual loading for long periods of time or the lack of access to Iranian museums and private collections.

Approximately, the most important manufacturing centers discussed in this study are Isfahan, Kerman $^{53}$, Shiraz, Mashhad, and Yazd in view of the concentrated guns and powder manufacturing in these cities. ${ }^{54}$

On the one hand, the archaeological evidence which has been offered by the artistic collection in this study proves the continuity of manufacturing powder flasks in Iran, until the second half of the $19^{\text {th }}$ century $\mathrm{AD} / 13^{\text {th }}$ century $\mathrm{AH}$. This is evident through the recorded year $1875 \mathrm{AD} / 1292 \mathrm{AH}$ on one of these flasks; ${ }^{55}$ that denies the common argument of the cease of this industry since the mid of this century after the Swiss, Jean Pauly, managed to manufacture a flask in the third decade of that century to combine the bullet flask and the load in one shot which has led up to the change of the operation and shooting systems to the percussion ignition system. On the other hand, the recorded year on the powder flask has another important value manifested in dating powder flasks of the same artistic design.

Seemingly, there are several ideal usages of powder flasks in loading hunting guns, not only pouring powder directly from the flask's nozzle to the gun's muzzle or pan. The optimal technique is to pour the powder first in a gunpowder measure that has a cylinder shape and chamfered edge nozzle. Some examples of these measures have come from Persia and they are kept in the Parviz Tanavoli collection and are ascribed to the $18^{\text {th }}$ or $19^{\text {th }}$ century $\mathrm{AD} / 12^{\text {th }}$ or $13^{\text {th }}$ century $\mathrm{AH}^{56}$. Besides, there are artistic types of powder flasks whose artistic designs include this measure with a mechanism to control the amount of powder. These designs have been supplied with two valves to open and close; the first allows the powder from the flask to the measure, then shuts; and the second pours the powder from the measure to the muzzle of the firearm.

Additionally, different sizes and weights of powder flasks are mainly traced back to the capability of firearms and the applications they have been specified for and the number of balls used. The variety unveils the mutual relationship among flasks' sizes and weights and the soldiers', on the one hand, and the size and weight of what soldiers carry of weapons and equipment, on the other, as it is commonly known in military science.

52Allan and Gilmour. Persian Steel, p.178.

53 Kerman was one of three important weapon manufacturing centres since the reign of Nader Shah, along with Isfahan and Merv. Farrok, Iran at War, pp.95, 174. This continued until the $19^{\text {th }}$ century AD/ $13^{\text {th }}$ century AH which is the same timing when Shiraz boasted with 17 ammunition factories for which black powder salt have been brought from Lār. Moreover, firearm muzzles, sword blades, and spear heads were manufactured and sold in the Arabian Gulf. Martin, The Qajar Pact: Bargaining, Protest and the State in Nineteenth-Century Persia, 31. Yazd has also been home for 21 factories. http://www.iranicaonline.org/articles/firearms-i-history (accessed 10 Aug. 2016).

54 Farrokh, Iran at War, p.147.

55 An evidence to support this is that the Metropolitan Museum in New York preserves a powder case with registration number "36.25.2374" made of steel and leather that ascribes to Persia holding the date 1895 - 1896 $\mathrm{AD} / 1331 \mathrm{AH}$ with dimensions $23.5 \times 6.5 \quad \mathrm{~cm}$ and weight of $87.9 \mathrm{~g}$. http:/www.metmuseum.org/art/collection/search/30470?sortBy=Relevance\&amp;deptids=4\&amp; $\mathrm{ft}=36.25 .23$ 74\&amp;pg=1\&amp;rpp=20\&amp;pos=21 (accessed 3 Aug. 2016).

${ }^{56}$ Allan and Gilmour, Persian Steel, pp.172- 176, fig. A.19-A.24.

- 157 - Persian Powder Flasks preserved in the Gayer- Anderson Museum in Cairo 
Furthermore, it is a necessity to link the relationship of the existence history of firearms ${ }^{57}$ and their kit in Persia including painting schools. From the Safavid to the Qajar dynasty, the wide spread of firearms which rely on black powder were observed which resulted in depicting Persian soldiers who carried their rifles ${ }^{58}$ on the shoulder and the back. Meanwhile, all the kit necessary for the rifles are kept in a belt pouch ${ }^{59}$; it consists of a leather belt which fastens around the waist and a sack, bag, flask, or pouch - two or three of them, specified to keep rifle balls, $\operatorname{shots}^{60}$, and some fire starter kit. Additionally, there are some miscellaneous items and other possessions, of which a big powder flask made of thick untanned leather that is as stiff as horns and another priming flask which is usually made of steel and holds good powder to load firearms ${ }^{61}$. It has left a general impression on Persian paintings and a specific one on Safavid and Qajar schools since there is a view of a soldier in a painting ascribed to Habib Allah of Mashadi which depicts the soldier, despite wearing a wide shawl tied around the waist, reaching his right hand in a waist pouch fixed to the belt, probably made of leather, which goes around his waist, picking some of its components (Pl. 16). It is the same pouch that seems hung to the man's belt in the painting which depicts "Bandits Attacking the Caravan of Aynie and Ria" and the soldier in gazelle hunting setting painted for Fath-Ali Shāh Qajar (Pl. 17). This relationship has a role in manifesting the value of studying the artistic elements in Persian painting and its different schools to uncover patterns of applied Persian artistic conventions.

Finally, this study reveals the artistic and manufactural diversity of the powder flasks collection at Gayer Anderson Museum, specifically some unique pieces of Persian powder flasks. Additionally, the study pays attention to the importance of the Persian artefacts in the Egyptian collections and museums generally, and the arms and armours particularly. No doubt, powder flasks require deeper studies to explore more aspects about the function, manufacture, and other shapes of them.

\footnotetext{
${ }^{57}$ A long history of firearms in Persia is documented but can hardly be included in this study. For more information, see: Matthee, Firearms in Persia, pp. 619-628; Cronin, Building a New Army, pp. 47-87; Farrokh, Iran at War, pp.5-243; http://www.iranicaonline.org/articles/firearms-i-history (accessed 24 July 2016).

${ }^{58}$ It is documented in some writings that members of the personal guard of Karim Khan Zand used "Flintlock Rifles" while other knights were equipped with "Matchlock Rifles". By the end of the $18^{\text {th }}$ century AD/ $12^{\text {th }}$ century $\mathrm{AH}$, these rifles were common among infantry soldiers in addition to small guns kept in waistbands, small bags to keep lead bullets, fire shots kept under the upper part of the left arm, and a powder case hung on the left side of the waistband. Farrokh, Iran at War, p.146.

${ }^{59}$ Some soldiers carried this pouch via a belt hung on the left shoulder and sags downwards to end in a pouch dangling on the right side. It was custom to make the pouch of black leather or the white leather of deer. Kibovskii and Yegorov, The Persian Regular Army of the First Half of the $19^{\text {th }}$ Century, Mark Conrad (Trans.), (1998), Available online at: http://marksrussianmilitaryhistory.info/PERSIA.html (accessed 1 Aug. 2016).

${ }^{60}$ There is an indication that "...Persians have make tolerably good powder but of coarse grain: bullets moulds are ordinarily constructed of stone; and shot is mostly imported from Europe, as well as flints...". Allan and Gilmour, Persian Steel, pp.176 - 177.

${ }^{61}$ It is worth referring to the depiction of muzzle loading with black powder from a powder flask on the left side of a double painting presenting Sultan Suleiman Hunting which is included among the second volume of Hünernâme manuscript, $1588 \mathrm{AD} / 996 \mathrm{AH}$, preserved in the library of Topkap1 Palace in Istanbul with registration number h.1524 and the painting is located on page 52 "fol.52a". It demonstrates two soldiers foregrounded, one of whom aiming a rifle at a deer placed before him and having a powder case in the form of a horn sagging next to a rectangular pouch. The second soldier, who is the researchers' focus, holds the muzzle with his right hand and rests the firearm on the ground while loading it from a powder case with his left hand, and has a pouch similar to the previous one sagging from his belt. Konak, Hünernâme II, foto.1.
} 


\section{ACKNOWLEDGMENT}

We are really grateful to Mr. Karam Abdel Hamid Mohamed, the former General Director of the museum of Gayer-Anderson, and Mr. Youssef Shaaban Abdel Aziz, the curator of Metals Department for their collaboration and help. Special thanks also go to Dr. Robert Elgood for his comprehensive review and helpful comments. Further thanks are due to SHEDET referees for their comments.

\section{REFERENCES}

- Ahmed (Ahmed Abd-al-Razik), Al-Hadārah al-Islamiyh fĩ al-'Isūr al-Wustá (Islamic civilization in the Middle Ages), Dar al-Fikr al-'Arabi, Cairo, (2004).

- Ahmed (Ahmed Abd-al-Razik), Al-Ranūk al-Islamiya (Islamic blazons), Faculty of Arts, Ain Shams University, Egypt, (2001).

- Aḥmed (Mamdūḥ Ramadān Mạ̣mūd), 'A 'mal al- 'äj wa-al- ’zm fĩ Miṣr mondh al- șrr al-Islāmi al-Mubakkir wa-httá Nihayat al- șr al-Mamlüki,(Ivory and bone works in Egypt from the early Islamic era until the end of the Mamluk era), M.Sc, Faculty of Archaeology, Cairo University, Egypt, (2000).

- Ágoston (Gábor), Guns for the Sultan: Military Power and the Weapons Industry in the Ottoman Empire, Cambridge University Press, New York, (2005).

- Al-Bahnasi (Șalaḥ Aḥmad), Fann al-Tașwīr fĩ al- Aṣr al-Islami, al-Taṣwīr al-Ṣafawi fĩ Irān waal- Othmani fĩ Torkiya wa-al-Maghulī fĩ al-Hind, Dar al-Wafă' li-Donya al-Ṭiba ah wa-alNashr, Al-Iskandariyah, (2016),

- Al-Bahnasy (Salah Ahmad), Al-Matahif 'Ilm wa-Fann, Cairo, (2010).

- Allan (James) and Gilmour (Brian), Persian Steel: The Tanavoli Collection, Oxford Studies in Islamic Art, (New York, (2000).

- Al-Kharrāt (Al-Mustafa Muhammad Ahmad), Tațawwur al-Aslihah al-Nariyah "al-Madāfi 'waal-Banādiq" wa-Athariha 'alá al-'Amā’ir al-Harbiyah bi-Mișr fĩ al-'Așr al- 'Othmāni wa-hattá Nihayat Hokm Muhammad 'Ali (1517-1848 AD/923-1265 AH): Diräsah Äthariyah Fanniayh Mi mariyah(The development of firearms "cannons and muskets" and their effect on the military architecture in Egypt in the Ottoman age until the end of of Muhammad Ali period (923-1265 AH/ 1517-1848 AD), Ph.D, University of Sohag, Egypt, (2011).

- Al-Nahar ("Ammār Mūhammad), "Al-Barūd al-Mutafajjir wa-al-Asliḥah al-Nāriyah wa-alMadfā'aiyah fī 'Așr al-Mamālīk(AD 1517-1250/ AH 648-923)", Majāllat al-Bahithūn al'Ilmiyah, Vol. 70, (2013), Available online at: http://www.albahethon.com/?page=show_det\&id=1746 (accessed on 18 July 2016).

- Al-Shakīl ('Ali Jam'an), Al-Kimiya' fĩ al-Hadārah al-Islamiyah, Dar al-Shurūq, Cairo (1989).

- Al-Shakīl ("Ali Jam'an), “Al-Qadhā'if wa-al-Aslihah al-Nariyah fĩ al-Haḍāah al-Islāmiyah”, Majāllat al-Thaqafah wa-al-Tūrāth, Markaz Jum'ah al-Majid lil-thaqafah wa-al-Tūrāth, Vol. 42, Dubai, (2003).

- Altungi (Muhammad), Mu'jam al-Mu'rrabāt al-Farisiyah mondh Bawakīr al-'Așr al-Jahili hatta al-'Așr al-Hadir, Al-Siba'i, Al-Siba'i Muhammad (Ed.), $2^{\text {st }}$ ed., Libraire du Libnan Publishers, Beirut, (1998).

- Ayalon (David), Gunpowder and Firearms in the Mamluk Kingdom: A Challenge to Medieval Society, Frank Cass, London\& New York, (1956).

- Brunner-Traut (Emma), Egyptian artists' sketches: figured ostraka from the Gayer-Anderson Collection in the Fitzwilliam Museum, Cambridge, Janine Burriau (Tans.), Nederlands Historisch-Archaeologisch Instituutte Istanbul, Leiden, (1979).

- Born (Wolfgang), "Ivory Powder Flasks from the Mughal Period", Ars Islamica, University of Michigan, Vol (9), (1942).

- Cronin (Stephanie), "Building a New Army: Military Reform in Qajar Iran", in Farmanfarmaian, Roxane (Ed.), War and Peace in Qajar Persia, Implications Past and Present, Routledge, London \& New York, (2008).

- 159 - Persian Powder Flasks preserved in the Gayer- Anderson Museum in Cairo 
- Daneshvari (Abbas), of Serpents and Dragons in Islamic Art: An Aconographical Study, Bibliotheca Iranica: Islamic Art and Architecture Series, No. (13), Mazda Publishers, (2011).

- Elgood (Robert), Firearms of the Islamic World: in the Tared Rajab Museum, Kuwait, I. B. Tauris, London and New York, (1995).

- Farrokh (Kaveh), Iran at War: 1500-1988, Osprey Publishing, Oxford, (2011).

- Foxcroft (Louise), Gayer-Anderson The Life and Afterlife of the Irish Pasha, The American University in Cairo Press, Cairo, (2016).

- Floor (Willem), "The Woodworking Craft and its Products in Iran", Muqarnas, Vol. (23), (2006).

- Group of scientists and researchers, Al-Mawsū'ah al-'Arabiyh al-'Alamiyah, Mu'asast A'amal al-Mawusū'ah lil-Nashr wa-al-Tawdhī’a, Vols (4, 5, 18, 23), AlRiyadh,(1999).

- Harper (Prudence Oliver), The Royal Hunter Art of the Sasanian Empire, Asia House, New York city, Dallas Museum of fine arts, The Cleveland Museum of Art, The Asian Society, Inc.(1978).

- Hușāf (Isma'īl Muhammed), Kordistān wa-al-Mas'alah al-Kordiyah(=Kurdistan and the Kurdish case), Mu'assasat Mukriyani lil-Bihouth, Arbil, (2009).

- Hindī (Ihsān), Al-‘Arab wa Ikhtra'a al-Barūd, Al-Tūrāth Al-'Arabi, Vol. (65), Damascus, (1996).

- Ibeachu (P.C.), Abu (E.C.), Didia (B.C.), Anthropometric Sexual Dimorphism of Hand Length, Breadth and Hand Indices of University of Port Harcourt Students", Asian Journal of Medical Sciences, Vol. (8), (2011).

- Kelényi (Béla) and Szántó (Iván), Artisans at the Crossroads: Persian Arts of the Qajar Period (1796-1925), Ferenc Hopp Museum of Eastern Asiatic Arts, Budapest, (2010).

- Khorasani (Manouchehr Moshtagh), Lexicon of Arms and Armor from Iran: A Study of Symbols and Terminology, Legat Verlag, Tübingen, (2010).

- Kibovskii (Aleksandr) and Yegorov (Vadim), The Persian Regular Army of the First Half of the Nineteenth Century, Mark Conrad (Trans.), (1998), Available online at: http://marksrussianmilitaryhistory.info/PERSIA.html (accessed 1 Aug. 2016).

- Konak (Ruhi), Hünernâme II, Cilt Minyatụrrlerinde Kompozisyon Düzeni, Ankara ụniversitesi Sosyal Bilimler Dergisi, (2014).

- Luft (Paul), The Qajar Rock Reliefs", Iranian studies, Vol. (34), (2001).

- Martin (Vanessa), The Qajar Pact: Bargaining, Protest and the State in Nineteenth-Century Persia, I.B.Tauris, London, (2005).

- Matthee (Rudi), "Firearms in Persia", in Encyclopedia Iranica, vol. (IX), Bibliotheca Persica Press, New York, (1999).

- Muhammad (Samar Faḍlá abd-al-Hamīd), Akrād al-Irāq taht Hokm abd-al-Karīm Qasim, M.Sc, Zagazig University, Egypt, (2010).

- Mujamm' al-Lughatu al-'Arabiyah, al-Mu'jam al-Wajiz, Ministry of Education, Special Edition, Cairo, (1999).

- Scarce (Jennifer M), Ancestral Themes in the Art of Qajar Iran 1785-1925", in BehrensAbouseif, Doris and Stephen Vernoit (eds.), Islamic art in the $19^{\text {th }}$ century: tradition, innovation, and eclecticism, Leiden, Boston, Brill, (2006).

- Sarmadi (Abbas), An Encyclopedia of the Artists in Iran and the Islamic world from Mani (3 ${ }^{\text {rd }}$ cent. AD) to Kamalulmulk (20 ${ }^{\text {th }}$ cent. AD), Hirmand publisher, Tehran, (2001).

- Sazonova (Natalia), Iranian Lacquer Work in the State Museum of Oriental Art: Catalogue of the Collection, Reading, Rustam Shukurov. (Trans), Moscow, MMXV, (2015).

- Shitá (Ibrahīm Al-Disūki), Al-Mu'jam Al-Farsi al-Kabīr: Farsi-'Arabi, Vol. (1), Madbouli Bookstore, Cairo, (1992).

- Shojanoori (Nikoo), A Background of Khatam Art, European Online Journal of Natural and Social Sciences, Vol. (3), No. (4), Special Issue on Architecture, Urbanism, and Civil Engineering, (2014).

- Simpson (Marianna Shreve), Persian Poetry, Painting and Patronage: Illustrations in a Sixteenth-Century Masterpiece, University Press, Yale, (1998). 
- Stone (George Cameron), A Glossary of the Construction, Decoration and Use of Arms and Armor in All Countries and in All Times, Dover Publications, New York, (1999).

- Swietochowski (Marie I.), "Habib Allah", in Persian Painting from the Mongols to the Qajars: Studies in Honour of Basil W. Robinson, Hillenbrand, Robert (Ed.), Pembroke Persian papers, Vol. (3). I.B. Tauris, London and New York, (2000).

- Taj (Ahmad), Al-Akrād Tarīkh Sha b wa-Qadiyat Wațan, al-Dar al-Thaqafiyah lil-Nashr, Cairo, (2001).

- http://armsandantiques.com/product/search?search=persian+powder+flask (accessed 30 July 2016).

- http://armsandantiques.com/18th-c-persian-safavid-black-wootz-powder-flask-ma424 (accessed 4 Aug. 2016).

- $\mathrm{http}: / /$ armsandantiques.com/19th-c-persian-gunpowder-flask-mf452 (accessed 5 Aug. 2016).

- http://art.thewalters.org/detail/2698/primer/ (accessed 21 July 2016).

- $\quad$ http://art.thewalters.org/detail/40388/powder-flask/ (accessed 21 July 2016).

- https://www.brooklynmuseum.org/opencollection/objects/10535 (accessed 6 Aug. 2016).

- $\mathrm{http}: / /$ cabinet.gov.krd/p/p.aspx?1=14\&s=020000\&r=353\&p=254 (accessed 24 Sep. 2016).

- http://www.cafr.ebay.ca/itm/ANTIQUE-INDO-PERSIAN-AFGHAN-GUN-POWDER-FLASKHORN-matchlock-jezail-musket-/371410964845 (accessed 5 Aug. 2016).

- http://www.christies.com/lotfinder/arms-armor/a-large-steel-and-brass-powder-horn-5422471details.aspx (accessed 30 July 2016).

- http://www.ebay.co.uk/sch/i.html? from=R40\& trksid=p2047675.m570.11313.TR0.TRC0.H1.X persian+powder+flask.TRS0\&_nkw=persian+powder+flask\&_sacat $=0$ (accessed 30 July 2016).

- http://www.fitzmuseum.cam.ac.uk/collections/egypt/collectionhistory/gayeranderson (accessed 19 Sep. 2016).

- $\quad$ http://www.iranicaonline.org/articles/barut-also-barut-and-barud-gunpowder-is-a-loanword-fromarabic-it-passed-from-turkish-into-persian-usage (accessed 24 July 2016).

- http://www.iranicaonline.org/articles/habib-allah-savaji (accessed 5 Aug. 2016).

- http://www.iranicaonline.org/articles/firearms-i-history (accessed 24 July 2016).

- http://www.iranicaonline.org/uploads/files/firearms i pl3.jpg (accessed 1 Aug. 2016).

- http://www.iranicaonline.org/articles/kurdish-language-i (accessed 24 Sep. 2016).

- http://www.michaelbackmanltd.com/2942.html (accessed 22 Sep. 2016).

- http://www.metmuseum.org/search-results\#!/search?q=powder\%20flask\&page=1 (accessed 4 Aug. 2016).

- http://www.metmuseum.org/art/collection/search/30470?sortBy=Relevance\&amp;deptids=4\&am $\mathrm{p} ; \mathrm{ft}=36.25 .2374 \& a m p ; p g=1 \& a m p ; r p p=20 \& a m p ; p o s=21$ (accessed 3 Aug. 2016).

- http://www.metmuseum.org/art/collection/search/35674 (accessed 3 Aug. 2016).

- http://www.metmuseum.org/art/collection/search/30438 (accessed 5 Aug. 2016).

- http://www.metmuseum.org/art/collection/search/30366 (accessed 1 Aug. 2016).

- http://mini-site.louvre.fr/trois-empires/fr/sculptures-incrustations-5-z2.php (accessed 21 July 2016).

- http://rch.ac.ir/article/Details?id=9440 (accessed 5 Aug. 2016).

- $\quad$ http://www.oriental-arms.co.il/item.php?id=4389 (accessed 4 Aug. 2016).

- $\mathrm{http} / / / \mathrm{www} .0$ riental-arms.co.il/item.php?id=4497 (accessed 21 Sep. 2016).

- http://oriental-arms.co.il/item.php?id=4180 (accessed 5 Aug. 2016).

- http://www.oriental-arms.com/item.php?id=6800 (accessed 5 Aug. 2016).

- https://rugrabbit.com/node/140845 (accessed 24 Aug. 2016).

- http://www.thirtyonehouse.com/\#!product/prd1/1991993765/18th-c.-persian-safavid-flask (accessed 30 July 2016).

- 161 - Persian Powder Flasks preserved in the Gayer- Anderson Museum in Cairo 